\title{
COMMENTARY
}

\section{JUDICIALIZATION: THE TWILIGHT OF ADMINISTRATIVE LAW}

\author{
LOREN A. SMITH*
}

At its December, 1984 Plenary Session, the Administrative Conference of the United States devoted a part of its agenda to an exchange of ideas on the current state of administrative law and the directions in which this field is likely to moveor be pushed-in the foreseeable future. Perhaps because modern administrative agencies are such a curious admixture of the political, bureaucratic, and judicial components of government, the study of administrative law derives particular benefits from analyses and critiques that emphasize social utility as well as legal precedent. In no other area of the law do the current political agenda and social climate affect so directly both the legal process and its end products.

The deliberately provocative essay that follows was written especially for this year's Administrative Law Issue by Loren A. Smith, Chairman of the Administrative Conference. Mr. Smith argues that the current level of judicialization and overproceduralization of the administrative process is a symptom of a fundamental dysfunction. He reminds us that formal methodologies cannot by themselves resolve the difficult issues that inevitably arise in the context of those important social programs placed under the auspices of the administrative agencies and argues that an infatuation with procedural safeguards-the traditional focus of administrative law studies-is counterproductive insofar as it has the effect of diverting attention away from critical substantive problems. "Hard looks," Mr. Smith concludes, may be a frustrated body politic's way of avoiding "hard choices," and he calls for a renewed recognition of the essentially political-and hence fully accountable-nature of the federal administrative process.

Copyright $\odot$ Loren A. Smith

* Chairman, Adninistrative Conference of the United States; Nominee to the United States Claims Court; J.D., Northwestern University.

I would like to thank Carole D. Iannelli, Jack M. Kress, Thontas M. Susnuan, Richard K. Berg, Jefferey S. Lubbers, Chief Judge Howard T. Markey, Chairman James C. Miller, III, Robert J. D'Agostino, Michael B. Wallace, Joseph A. Morris, Robert F. Freer, Jr., Michael W. Bowers, William C. Bush, Mary Candace Fowler, Charles Pou, Jr., and David M. Pritzker for their important help, wise counsel, and constructive criticism in connection with the writing of this essay. A special note of appreciation is due to Chief Judge Robinson O. Everett of the United States Court of Mihtary Appeals, who provided me with the opportunity to address this topic before his court's excellent judicial conference, and then, along with Eugene R. Sullivan, convinced me to undertake the task of reworking ny talk for publication.

Of course, the views expressed here are ny own, and should not be attributed to the Adninistrative Conference or any of the individuals uamed above. 
"The danger is not that a particular class is unfit to govern. Every class is unfit to govern."'

The "judicialization of the administrative process" is a phrase descriptive of several related phenomena. It is probably used most often to refer to the active participation of the courts, through extensive judicial review, im the decisions of executive bodies. ${ }^{2}$ But it can also refer to the expanding use of trial-like procedures for making governmental decisions, ${ }^{3}$ and, more generally, to overproceduralization and excessive complexity in the process of making public policy decisions. ${ }^{4}$ This essay is

1. LoRd Acton, Letters of LoRd Acton to Mary Gladstone 93 (H. Paul ed. 1904).

2. See generally Chayes, The Role of the Judge in Public Law Litigation, 89 HARV. L. Rev. 1281 (1976); Cramton, Judicial Law Making and Administration, 36 PUB. AD. Rev. 551 (1976); Horowitz, The Courts as Guardians of the Public Interest, 37 PuB. AD. Rev. 148 (1977); Kidney, Are Judges Getting Too Powerful?, U.S. NEWS \& WorLd REP., Jan. 16, 1978, at 39; Press, When Judges Govern, NEwsweEk, Aug. 13, 1979, at 79; Symposium on Judicial Activism: Problems and Responses, 7 Harv. J. L. \& Pub. Pol'y 1 (1984). One focus of the scholarly attention given in recent years to aggressive judicial review of administrative programs and decisions has been the proper use of the Constitution by the judiciary in this context. The major schools of thought on this issue are reviewed in Brest, The Fundamental Rights Controversy: The Essential Contradictions of Normative Constitutional Scholarship, 90 Yale L.J. 1063 (1981), and Stewart \& Sunstein, Public Programs and Private Rights, 95 HARV. L. REv. 1193 (1982).

3. Sec, for example, the "hybrid" rulemaking procedures of the Magnuson-Moss WarrantyFederal Trade Commission Inprovement Act, Pub. L. No. 93-637, § 202, 88 Stat. 2183, 2193 (1975) (codified, as amended, at 15 U.S.C. $\S 57$ a (1982)). Reviewing courts have also contributed significantly to this trend, imposing, if not always "courtroom-like procedures," at least additional non-statutory procedural requirements on various kinds on agencies. See, e.g., Home Box Office, Inc. v. FCC, 567 F.2d 9, 58 (D.C. Cir.) (requiring evidentiary hearings to determine the nature of certain ex parte FCC contacts), cert. denied, 434 U.S. 829 (1977); Mobil Oil Corp. v. FPC, 483 F.2d 1238,1264 (D.C. Cir. 1973) (evidentiary procedures in a ratesetting proceeding must be sufficiently adversarial in nature to provide a reasonable guarantec of reliability). This judicial developinent was stemmed by the Supreme Court's opinion in Vermont Yankee Nuclear Power Corp. v. Natural Resources Defense Council, 435 U.S. 519 (1978), in which it was held that the courts may not superimpose their own ideas of appropriate administrative procedure if agencies' elroices have met the minimum standards of the Administrative Procedure Act. See Scalia, Vermont Yankee: The $A P A$, the D.C. Circuit, and the Supreme Court, 1978 SuP. CT. Rev. 345; Verkuil, The Emerging Concept of Administrative Procedure, 78 Colum. L. Rev. 258, 288-90 (1978). But cf. Goldberg v. Kelly, 397 U.S. 254 (1970) (fourteenth amendment requires that state welfare termination procedures include an adversarial pretermination hearing with certain trial-like characteristics); Cleveland Bd. of Educ. v. Loudermill, 53 U.S.L.W. 4306 (U.S. Mar. 19, 1985) (pretermination opportunity to be heard constitutionally required in connection with dismissal of a state employee dischargeable only for canse).

4. The National Enviroumental Policy Act of 1969, 42 U.S.C. $\S \S 4321-4347$ (1982), and the Government in the Sunshine Act, 5 U.S.C. $\S \S 551-552,552 b, 556-557,5$ U.S.C. app. $\S 10$ at 983,39 U.S.C. $\S 410$ (1982), which apply to a wide range of government activities, are examples of this proceduralization, inuch of which is directed at ensuring opportunities for participation by interested parties in the policymaking process. See Stewart, The Reformation of American Administrative Law, 88 HARV. L. REV. 1669, 1670 (1975) ("Increasingly, the function of adininistrative law is not the protection of private autononny but the provision of a surrogate political process to ensure the fair representation of a wide range of affected interests in the process of administrative decision."). 
about all of these manifestations of judicialization, because they all reflect a common underlying trend in our polity.

The thesis of this essay is that modern administrative law increasingly has fallen victim to self-deception. A significant part of administrative law theory is based on a fallacy as dysfunctional in that system as the belief in a two-dimensional earth was for the geography of the fifteenth century. The fallacy is that we can nuake social and econormic decisions by means of formal processes and legal procedures without the exercise of political will. We have come to believe that public liearings, public disclosure of all documents relevant to a given issue, and trial-type methodologies for testing ideas will lead to "better" social and economic policies by government decisionmakers having power over large sections of the economic and social life of the nation. This attitude leads to an excessive focus on the process rather than the substance of governmental decisions. It is a fallacy that diverts us from the recognition that a government's decisions must ultimately be judged by the values embodied in that government's constitutional mandate-that is, by moral values derived from the society's culture and traditions. Government ultimately must be judged by such substantive moral standards if the terms "good government" and "bad government" are to lave any ineaning.

Of course, procedures and courts do have a role to play. They act as instruments of restraint. They keep-rather than make-the political systein democratic and constitutional. At their best they function as the banks of a great river; they keep government from inundatimg the land. 5 But procedures and courts can make governmental decisions substantively "better" only when the decisions to be made are judicial rather than political in character. ${ }^{6}$ Entrusting by default the task of political decisionmaking - and most significant government decisions have a large political component-to those who are constitutionally bound to disclaim that role is to engage in sleight of hand; the real decisionmakers

5. Justice Cardozo used a variant of this metaphor with reference to the delegation of legislative power in his dissent in Panama Refining Co. v. Ryan, 293 U.S. 388, 440 (1935) (Cardozo, J., dissenting) (the discretion granted "is not unconfined and vagrant. It is canalized within banks that keep it from overflowing.").

6. Consider in this context Chief Justice Marshall's remarks in Osborn v. Bank of the Umited States, 22 U.S. (9 Wheat.) 738, 818-19 (1824) (emphasis added):

[T]he legislative, executive, and judicial powers, of every well constrncted government, are co-extensive with each other; that is, they are potentially co-extensive. . . . All governments which are not extremely defective in their organization, must possess, within themselves, the means of expounding, as well as enforcing, their own laws. If we examine the constitution of the United States, we find that its framers kept this great pohitical principle in view. ....

[The "arising under" clause of article III] enables the judicial department to receive jurisdiction to the full extent of the constitution, laws, and treaties of the Umited States, when any question respecting them shall assume such a form that the judicial power is capable of acting on it. 
and the full dimensions of their political decisions are kept out of sight and thereby escape rigorous social review. To the extent that we judicialize government, we necessarily tend to see the failures of economic and social programs not as manifestations of wrong-headed policies, but as bad technique or the flawed work of wrong-headed administrators. Such an orientation paralyzes our political system, makes policy direction increasingly less relevant, and leads to increased dissatisfaction with government. Thus, judicialization-the comprehensive expression of the fallacy I am describing - masks real policy disputes and problems with an ephemeral debate over procedure and the structure of governmental decisionmaking. In some ways this result may be comforting for political leaders and voters who cannot make up their minds on the policies they wish to follow. It does not, however, respond to society's need for real solutions to concrete problems or fulfill the duty of government or the legal profession to develop a procedural scheme that preserves fundamental constitutional values and real democratic choice. To paraphrase an enemy of constitutional democracy, law becomes a political opiate for those acting under the illusion of judicialization.

One especially important effect of the fallacy of judicialization on current administrative law theory is manifested in the confusion of two radically different aspects of public government-that is, of public decisionmaking. The first involves decisions of will. We generally refer to these decisions as "political" or "democratic" or "policy" decisions. The second mode is based on decisions of logic. These are decisions that we generally describe as "legal" or "judicial." Despite the inevitable overlap, these two classes of decisions have very different characteristics. Decisions of will typically are subjective. There is often no "right" answer to the problem calling for such a decision. A classic, albeit homely, example is whether the fence around the city hall should be painted blue or white. We summarize this concept by the term "discretion." The premise behind decisions of logic, on the other hand, is that they are objective, at least within a given culture or legal system. With respect to decisions of this second type, typically there will be one answer that will be found to be the most consistent with a given social reality. A simple example is the determination whether a particular person has reached the eighteenth-year age threshold that would allow him to vote. The inquiry will be based upon factors totally unrelated to thouglits about whether it would be nice or nasty for that person to be a voter. A person has a right to vote if he is eigliteen and does not have that right if he is not eighteen; the task is to decide if a particular individual meets that criterion. Such a decisionmaking process does not depend upon an exercise of will or subjective judgment. The age threshhold is taken as a given and applied 
deductively, and, of course, the unexamined premise of what is the "best" minimum age for voters is based on a previously made decision of will.

Both types of decisions have their appropriate places in our polity. However, because they are functionally different at a fundamental level, it is to be expected that the methods and institutions appropriate for one type of decisionmaking will be highly mappropriate for the other type. Likewise, one could infer that the subject matter fit for decisions of will-what color to paint the fence, for example - cannot be properly addressed by the other mode. The "right" color cannot be selected by a computer program - or by any other set of purely logical procedures. A confusion of these two types of decisions and their attendant processes is dysfunctional and endangers both the constitutional framework and operational efficiency of government. ${ }^{7}$

In fact, a significant confusion of the modes of governmental decisionmaking has occurred in our system. This confusion is an effect of the judicialization fallacy and manifests itself in an overvaluation of the decision of logic in the public pohicy arena and the concomitant overvaluation of that type of decisionmaking's optimal institution, the fully procedurahized court. The corollary of this trend has been the undervaluation of the decision of will, which does not appear to have an optimial institutional form. Although the sole administrator, with total discretion within the limits of the agency's mandate, is a prime example of an institution designed for making decisions of will, the traditional New England town meeting is an equally valid model, as is the referendum. However, these models can only approximate the archetype of the decision of will, which is the individual acting in a private capacity. Thus, perhaps, government always has a bias toward the decision of logic. It is, after all, the type of decision nost consistent with the collective character of government, while the decision of will is in its purest form a private act. 8 In denocratic constitutionalism, however, both decisionmaking

7. Separation of these two types of decisionmaking powers serves to balance the will of the majority against the rights of individuals.

[T] here is no liberty, if the judiciary power be not separated from the legislative and executive. Were it joined with the legislative, the life and hiberty of the subject would be exposed to arbitrary control; for the judge would be then the legislator. Were it joined to the executive power, the judge might behave with violence and oppression.

Montesquieu, The SPIRIT of The LAws 152 (T. Nugent trans. 1949) (bk. XI). See also ThE FEDERALIST No. 47 (J. Madison) (discussion of the separation of powers provided for by the United States Constitution). See Horowitz, supra note 2, at 151-54, for a discussion focused specifically on the inadequacy of the judicial decisionmaking process for making policy determinations.

8. In certain ancient civilizations, there was no distinction made between the law and the private will of the deified ruler. But as societies grew more complex, the dichotomy between goverument and the private will of those who govern became an essential part of political and legal theory. 
modes are necessary, and the balance between them affects the health of the body politic.

And even if there is an inherent bias in governments toward the decision of logic and away from that of will, it still is important to ask why this tendency seemingly has been exaggerated in the course of the last generation. Why has this relatively recent trend overvalued the type of decisions produced by the judicial structure? Perliaps more importantly, in what ways has this bias manifested itself, and what have been the effects on the functioning of government and the direction of public policy? And finally, what are the alternatives to an overly judicialized governmental system? I would like to offer some thoughts on these issues in the context of the federal governinent. But this is not to say that the problem is confined to the national part of our constitutional system. Preliminary readings on the debate in the states on the subject of the legislative veto and some studies of specific state regulatory processes strongly indicate that the problem is very real at that level as well.9

\section{The Dysfunction in Context}

To analyze the seductiveness of the judicial model of public decisionmaking, and its effect on the federal system, one has to look to the origins of American administrative law. More than one scliolar has

See generally E. Voegelin, The NEw SCIENCE of Polmics 27-75 (1952). The basic issues raised by this dichotomy are still with us today. Although we are committed to a presidency closely circumscribed by law, we also yearn for a president who has all the wisdom, compassion, energy, courage, and leadership humanly possible. The "strong-president" debate is a key theme in our pohitics, and can be seen as but one example of our desire to import into our government more effective institutions for making decisions of will.

9. See generally, eg., Legislative Improvement and Modernization Comm., NAtional Conference of State Legislatures, Restoring the Balance (1979) (recommending legislative review of administrative regulations); M. PRICE, ExECUTIVE CONTROL of RULEMAKING: THe OfFICE OF Administrative LAW IN CALIForNia (1980) (report prepared for and published by the Administrative Conference of the U.S.); Bonfield, The Iowa Administrative Procedure Act: Background, Construction, Applicability, Public Access to Agency Law, The Rulemaking Process, 60 IowA L. Rev. 731 (1975); Fuchs, Judicial Control of Administrative Agencies in Indiana: I, 28 IND. L.J. 1 (1952); Levinson, Legislative and Executive Veto of Rules of Administrative Agencies: Models and Alternatives, 24 WM. \& MARY L. REv. 79 (1982) (an examination of the use of the legislative veto in various states, concluding that it should not be used); Schotland, Judicial Review of State Administrative Action, 26 AD. L. REv. 93 (1974) (arguing for increased education of state judges on the subject of administrative law); Taylor, Legislative Vetoes and the Massachusetts Separation of Powers Doctrine, 13 SUFFOLK U.L. REv, 1 (1979) (concluding that a legislative veto of executive action violates the Massachusetts Constitution). See also the reports prepared by the staff of the New York State Assembly's Administrative Regulations Review Commission: Legislative Oversight of Administrative Rulemaking (1977); Public AcCess to Rulemaking: A Comparative Study of the Federal and State Administrative Procedure Acts (1978); State Agencies and the State administrative Procedure Act: A STUDY OF COMPLIANCE (1977). 
noted that adininistrative law in the broadest sense dates froin the inception of the nation; $;^{10}$ to the extent that one defines administrative law as the control of government administration by general legal principles, administrative law is a necessary aspect of constitutional government. It is more useful, however, to view administrative law as a comprehensive system of specific legal rules and judicial precedents governing the way government makes decisions affecting the private rights of individuals. Even under this narrower definition one can find examples of adininistrative law dating back to the earliest days of the Republic, ${ }^{11}$ and before that to the jurisprudence of England. ${ }^{12}$ But it was not until the latter part of the nineteenth century that the federal government began to have a inajor inpact upon the private rights of individuals. Government intervention into the sphere of private rights increased dramatically during and following the War Between the States, ${ }^{13}$ and the creation of the Interstate Commerce Commission (ICC) in $1887^{14}$ inarked a symbohic turning point $\mathrm{m}$ the evolutionary process. In the ICC, the first of the independent regulatory agencies, we find the model for ongoing federal imstitutional involvement with private rights. ${ }^{15}$ It was this historical

10. K. Davis, ADMinistrative LaW 6-7 (1977); J. Dickinson, Administrative Justice AND tHe Supremacy of LAW in the UNTEd STATES 5 n.5 (1927); W. GellhorN, Federal ADM1NISTRATIVE PROCEDURES 4-5 (1941).

11. See, e.g., W. GELLHORN, supra note 10, at 4-7 (regulation of oceangoing vessels, the coastal trade, and customs); E. Freund, R. Fletcher, J. DAvies, C. Pound, J. KuRTZ \& C. NAGEL, The Growth OF AMERICAN ADMINISTRATIVE LAw 16-20 (1923); see also O. HANDLIN \& M. HANDLIN, COMMONWEALTH: A STUdY OF THE ROLE OF GOVERNMENT IN THE AMERICAN ECONOMY: MASSACHUSETTS, 1774-1861, at 229-44 (rev. ed. 1969) (discussing the "reform state").

12. See W. Dicey, The LaW of the Constitution 189 (8th ed. 1915); F. Goodnow, CoMPARATIVE ADMINISTRATIVE LAW 6-7 (1893); see generally E. HENDERSON, FOUNDATIONS OF ENGLISH ADMINISTRATIVE LAW (1963) (an examination of the relationship between the courts and adininistrative bodies in the 1600 's).

13. To take but one example-and setting to one side the enormous powers appropriated by the President during the Civil War and by Congress in subsequently encouraging the growth of railroads and other business schennes-the civil rights measures enacted during Reconstruction to protect the rights of freedinen drastically extended the reach of the federal government. In vetoing one such act, President Andrew Johnson characterized it as establishing safeguards " 'which go infinitely beyond any that the General Government has ever provided" " and as " an absorption and assumption of power by the General Government which, if aequiesced in, inust sap and destroy our federative system of limited powers." " E. MCKITRICK, ANDREW JOHNSON AND RECONSTRUCTION 315 (1960); see also K. STAMPP, THE ERA OF ReCONSTRUCTION: 1865-1877, at 112, 132 (1965). While these new powers were not then utilized in the area of what we think of as adininistrative law, and not utilized at that time as extensively as in later years, the inere fact that President Johnson's vetoes were overriden so readily indicated a new, radically different mindset about the role of the federal governinent in our national life.

14. Interstate Commerce Act of 1887, ch. 104, § 11, 24 Stat. 379, 383.

15. See L. JAfFe \& N. NATHANSON, Administrative LAW 4, 14 (1968). Traditionally, students of administrative law have been fascinated with and focused their attention on the workings of the independent regulatory agencies. See, e.g., B. SCHWARTZ \& H. WADE, LEGAL CONTROL OF GOVERNMENT: ADMINISTRATIVE LAW IN BRITAIN AND THE UNITED STATES $26-29$ (1972). 
development that necessitated the creation of an explicit and coherent set of judicial and legislative principles out of which the fabric of modern admimistrative law has been woven. Our inquiry into the present state of admimistrative law might benefit, therefore, by a glance at the context in which this system began.

There were several general reasons put forward for the creation of the ICC, and analogs to them recur with respect to the numerous other independent regulatory boards and commissions that later followed its pattern. ${ }^{16}$ These reasons seem to me to be directly relevant to the issues raised by the coexistence of the two fundamentally different types of governmental decisionmaking described earher. At the core of the underlying rationale was a pohitical critique of the free market's ability "fairly" to set prices in certain areas of the economy. ${ }^{17}$ In the case of the ICC, of course, the concern was railroad rates. But it must be remembered that this view was put forward in the context of a general social commitment to private economic freedom. ${ }^{18}$ The pohtical theory of the proponents of economic regulation was that monopolistic conditions prevailed in the railroad industry, or at least that railroads possessed disproportionate bargaining power relative to shippers. ${ }^{19}$ For their part, the shipping interests had vastly superior voting power at their command. These were the factors that, in part, supplied the political justification for governmental intervention in favor of the shippers. Of course, this debate grew out of a much broader political controversy that pitted different economic interests and geographic regions against one another. ${ }^{20} \mathrm{All}$ in all, it was a classic battle of will.

The ultinate outcome of this battle could have been any of a number of possible political solutions: government seizure and owner-

16. B. SchWARTZ \& H. WADE, supra note 15, at 27-29; see generally M. BERNSTEIN, REGULATING BUSINESS BY INDEPENDENT COMMISSION (1955); R. CUSHMAN, THE INDEPENDENT REGULATORY COMMISSIONS (1941); A. KAHN, THE ECONOMICS OF REGULATION (1971).

17. See D. Boies \& P. Verkuil, Public Control of Business 50-60 (1977).

18. Id. Cf. In re Consolidations and Combinations of Carriers, and Communities of Interest Therein, Their Rates, Facilities and Practices, 12 I.C.C. 277, 305 (1907) ("competition between railways as well as between other industries is the established policy of the nation").

19. See S. Breyer \& R. Stewart, Administrative LaW and Regulatory Policy 13 (1979); R. POSNER, ECONOMIC ANALYSIS OF LAW chs. 9-12 (2d ed. 1977); B. WEISBROD, J. HANDLER, \& N. KOMESAR, PUBlic INTEREST LAW: AN ECONOMIC AND INSTITUTIONAL ANALysis ch. 2 (1978).

20. The political explanation for the creation of the ICC and the motives of the various interest groups involved have been the subject of considerable controversy. See, e.g., D. Boles \& $\mathrm{P}$. VERKUIL, supra note 17, at 17-25, 56-63; S. BREYER \& R. STEWART, supra note 19, at 23-24; S. Buck, The Granger Movement 11-15 (1913). See generally G. Kolko, Railroads and RegUlation (1965) (historical overview); I. Sharfman, THE INTERSTATE COMMERCE COMMISSION (1931) (detailed multi-volume history); Purcell, Ideas and Interests: Businessmen and the Interstate Commerce Act, 54 J. Ам. Hist. 561 (1967). 
ship of the railroads; the creation of private causes of action against railroads for unfair rates; the elimination of certain market imperfections such as the government grants to the railroads; no action by government; or the actual solution of government regulation. Regulation was perhaps the most likely result because at its heart it is a pohtical rather than an economic or legal approach, and one consistent in theory with the concept of police power known to the Enghish polity and common law for so long. ${ }^{21}$ Regulation also represents the thing politicians like most in this imperfect world-a comproinse. The very premise of regulation is that private decisionmaking is generally good, but needs government controls to make it better. Why else do we regulate rather than take over or leave alone? In fact, regulation is a necessarily imperfect compromise on the most basic political question any society must answer: what is the proper sphere of the state and the proper sphere of the individual? Regulation always ultimately rests upon this intellectual compromise-even though the coinpromise might be criticized as philosophical quicksand. Inherent in this shifting foundation is the host of problems that are the province of administrative law. Inherent also is a struggle between majorities and mimorities, that is, between those favoring decisions of will and those favoring decisions of logic.

Several important concepts that underpin current admimistrative law can be found in the theory and structure of the independent regulatory agency. First, there is the need to justify government intervention in the face of the American constitutional norm of freedom. Historically, monopoly has been the most significant of these justifications. ${ }^{22}$ Other justifications include the iguorance of users and purchasers of goods and services with respect to complex or technical issues, ${ }^{23}$ the perceived rapa-

21. See, e.g., 1 W. Blackstone, Commentaries *263-68, *415-16 (describing the King's "prerogatives" as "arbiter of [domestic] commerce" and a statute restricting the practice of trades to those persons who have served as apprentices).

22. Prior to 1920 , economic regulation was aimed primarily at preventing monopoly abuses. The Interstate Commerce Act of 1887, ch. 104, 24 Stat. 379, the Sherman Antitrust Act, ch. 647, 26 Stat. 209 (1890), the Clayton Antitrust Act, ch. 323, 38 Stat. 730 (1914), and the Federal Trade Commission Act, ch. 311, 38 Stat. 717 (1914), were all directed at problems associated with concentrated economic power. However, the Transportation Act of 1920, ch. 91, 41 Stat. 456, ushered in a new era of regulation that attempted to manage industries in the "public interest," protecting both established firms and the public from abusive practices or other problems created by too much competition. See Noll, The Economics and Politics of Regulation, 57 VA. L. REV. 1016, 1026-28 (1971).

23. The Federal Food and Drugs Act of 1906, ch. 3915, 34 Stat. 768, repealed by Federal Food, Drug, and Cosmetic Act, ch. 675, 52 Stat. 1040 (1938), is an early example of regulation designed to protect consumers from hazards they cannot be expected to uncover themselves. See J. WiLsoN, The Polrtics of Regulation 192-201 (1980). A more recent example is the Consumer Product Safety Act, Pub. L. No. 92-573, 86 Stat. 1207 (1972). 
cious nature of certain industries, ${ }^{24}$ and the need for a comprehensive national regulatory scheme that a common law system, working alone, would be unable to achieve. ${ }^{25}$ It is essential to consider these underlying pohitical justifications for estabhishing regulatory bodies when evaluating the appropriate locus and nature of decisionmaking functions within such governmental programs. This is so because in our constitutional system the permissible uses of and limitations upon a power are directly related to if not dependent upon the rationale for the legislature's action. ${ }^{26}$

What should be noted about these justifications for government intervention is that they are all premised on the need to exert governmental power in favor of certain values. Governmental power aids competition, collective bargaining, the flow of information, automobile safety, and so on. But this ineans that government inust make decisions of will that run counter to the decisions of will - the values - of many citizens. By imposing automobile safety standards, for example, government favors the values of consuiners who want safer cars over those who want cheaper or faster cars. Whatever one inay think of this policy, it is just that, a policy, an act of pohtical will that does not imvolve questions of "rights." It nay in fact create or destroy rights, but it is not a decision about rights.

A policy decision such as one on automobile safety standards is not a decision of logic, but it can be made to appear so by arguing that it is a decision mandated by a concern for mdividual rights. The argument goes soinething like this: Government has a duty to protect the rights of its citizens; unsafe cars threaten to kill or injure mdividuals other than

24. Regulation of the securities markets following the collapse of the stock market in 1929 falls into this category.

25. E.g., The Wagner Act, ch. 117, 46 Stat. 1084 (1931) (providing for the planning and construction of public works, industrial stabilization, and the alleviation of unemployment) (the National Resources Planning Board was abolished by Act of June 26, 1943, ch. 145, tit. I, 57 Stat. 169, 170, rendering the Waguer Act obsolete; certain provisions were formally repealed in 1966); National Labor Relations Act, ch. 372, 49 Stat. 449 (1935). Early regulation of the communications imdustry and the safety aspects of common carrier regulation are other examples of national regulatory schemes. Constitutional limitations upon the courts and practieal limitations on the Congress made executive branch regulation necessary to establish national standards in these areas.

26. See McCulloch v. Maryland, 17 U.S. (4 Wheat.) 316, 421 (1819):

We admit, as all must admit, that the powers of the government are limited, and that its himits are not to be transcended. But we think the sound construction of the constitution must allow to the national legislature that discretion, with respect to the means by which the powers it confers are to be carried into execution, which will enable that body to perform the high duties assigued to it, in the manner most beneficial to the people. Let the end be legitimate, let it be withm the scope of the constitution, and all means which are appropriate, which are plainly adapted to that end, which are not prohibited, but consist with the letter and spirit of the constitution, are constitutional.

On the current status of constitutional scrutimy of legislative actions affecting the economy, see the debate between Judge Scalia, Economic Affairs as Human Affairs, 4 CATO J. 703 (1985), and Professor Epstein, Judicial Review: Reckoning on Two Kinds of Error, 4 CATo J. 711 (1985). 
those who voluntarily purchased them, and additional costs are imposed upon society in the form of higher autoinobile and medical insurance rates, all because of technical defects in the less safe cars; therefore, government must take action to protect the "rights" of all drivers and insurance-premium payers by imposing stringent safety standards. The fallacy in this syllogisin hes in the concept of "rights" that it miplies. So broad a notion of rights would require the state to protect its citizens from all preventable harm, and that in turn would require it to abrogate freedoms whenever necessary to achieve that end. Under such a conceptual approach, freedom would be an essentially meaningless notion because all freedoin can potentially harm other human beings. If "rights" and pohicy are confused im this way, it can be argued that restrictive government power must always be exercised when the potential harm posed by freedom becomes significant to any degree.

I am not necessarily arguing against the use of the power of the state for the purpose of aiding certain values. That is a question involving prudence in the Burkean sense. ${ }^{27}$ It is, however, critical to understand that when such power is used it is an act of political will the sources of which cannot be found in a theory of rights. Each such act of will must be justifiable in terns of the values of the society as expressed in its constitution and, when constitutionally permissible, the society's political and economic goals, and the resulting action's efficaciousness.

A second important underpinning of our systein of administrative law is the notion of procedural due process as a necessary check upon the impleinentation of majoritarian pohtical decisions by means of administrative action. ${ }^{28}$ Historically, this limitation was conceived of as a libertarian device. ${ }^{29}$ If, in the name of certain political goals, government was to intrude upon what had traditionally been recognized as individual rights at the very heart of our constitutional trimity of life, liberty, and property, then our Constitution seemed to inandate soine protection of these minority rights. If freedom had to be limited, it should not be trampled. The traditional means of such protection are, of course, the courts. It has been the courts' historic role to confine executive agents to their statutory cliarters and the statutory charters to their constitutional

27. "Your representative owes you, not his industry only, but his judgment; and he betrays instead of serving you if he sacrifices it to your opinion." E. BURKE, Speech to the Electors of Bristol, in Edmund Burke on Government, Polmics AND Society 157 (B. Hill ed. 1976).

28. See Note, Specifying the Procedures Required by Due Process: Toward Limits on the Use of Interest Balancing, 88 HARV. L. REV. 1510, 1524-27 (1975).

29. See Stewart \& Sunstein, supra note 2, at 1311-15. 
bases. ${ }^{30}$ With specific reference to the regulation of private economic rights, however, rehance on constitutional protection was largely overthrown in the late 1930's by the demise of substantive due process review $^{31}$ and an expansive reinterpretation of the coinmerce clause. ${ }^{32}$ In reaction to the significant governmental growth ushered in by this change in judicial philosophy, the New Deal programs, and World War II, and as a countermeasure to widely perceived agency overreaching, the Administrative Procedure Act (APA) ${ }^{33}$ was enacted in 1946. The APA seemed to provide the political system with yet another form of compromise, one which protected private riglits from obviously arbitrary and uninformed administrative actions directed against them. ${ }^{34}$

A serious systemic problein of constitutional proportions in the executive brancli was noted at the very leyday of the New Deal. Reporting in 1937, a cominittee set up by President Roosevelt observed that the "Executive Branch of the Government of the United States lias . . . grown up without plan or design like the barns, shacks, silos, tool slieds, and garages of an old farm. To look at it now, no one would ever recognize the strncture which the founding fatliers erected a century and a half ago."35

[The independent regulatory commissions] have been the result of legislative groping rather than the pursuit of a consistent policy. . . . ... They are in reality miniature independent governments set up to deal with the railroad problem, the banking problem, or the ra-

30. See generally L. JAFFe, JUdicial. ConTrol OF ADMinistrative ACTION 320-94 (1965); Rostow, The Democratic Character of Judicial Review, 66 HARv. L. REv. 193, $195-99$ (1952) (discussion of the history and nature of federal judicial review of legislative action).

31. See, e.g., Wickard v. Filburn, 317 U.S. 111 (1942); United States v. Carolene Products Co., 304 U.S. 144 (1938); NLRB v. Jones \& Laughlin Steel Corp., 301 U.S. 1 (1937); West Coast Hotel Co. v. Parrish, 300 U.S. 379 (1937); Nebbia v. New York, 291 U.S. 502 (1934); L. TRIBE, AMERICAN CONSTITUTIONAL LAW 432-51 (1978) (tracing the development of substantive due process review of economic legislation from the Slaughterhouse Cases, 83 U.S. (16 Wall.) 36 (1873), to Lochner v. New York, 198 U.S. 45 (1905), and through the latter case's decline in the late 1930's).

32. See, e.g., Wickard v. Filburn, 317 U.S. 111 (1942); United States v. Darby, 312 U.S. 100 (1941); NLRB v. Jones \& Laughlin Steel Corp., 301 U.S. 1 (1937); Stern, The Commerce Clause and the National Economy, 1933-46, 59 HARV. L. REv. 645 (1946); see also Eule, Laying the Dormant Commerce Clause to Rest, 91 YALE L.J. 425, 432 (1982); Maltz, How Much Regulation is Too Much-An Examination of Commerce Clause Jurisprudence, 50 GEO. WASH. L. REv. 47 (1981). Cf. Garcia v. San Antonio Metropolitan Transit Auth., 53 U.S.L.W. 4135 (U.S. Feb. 19, 1985) (overruling National League of Cities v. Usery, 426 U.S. 833 (1976), which had provided the states' "traditional" governmental functions with imununity from counnerce clause legislation).

33. Ch. 324, 60 Stat. 237 (1946) (codified, as amended, at 5 U.S.C. $\S \S 551-559,701-706,1305$, $3105,3344,4301,5335,5372,7521(1982))$.

34. For a saminary of the events leading up to the passage of the Adininistrative Procedure Act, see Burchell, The Administrative Procedure Act, 22 I.C.C. PrAc. J. 375, 375-79 (1955); Verkuil, supra note 3, at 261-76.

35. The President's Committee on Administrative Management, Administrative MANAGEMENT iN THE GOVERNMENT OF THE UNITED StATES 32 (1937). 
dio problem. They constitute a headless "fourth branch" of the Government, a haphazard deposit of irresponsible agencies and uncoordimated powers. . .

. . . There is a conflict of principle involved in their inake-up and functions. ... [T] hey are vested with duties of administration and pohicy determination ...., and at the same time they are given important judicial work . . . .

The evils resulting froin this confusion of principles are insidious and far reaching. ...

... Pressures and influences properly enough directed toward officers responsible for formulating and administering policy constitute an unwholesoine atmosphere in which to adjudicate private rights. But the mixed duties of the commissions render escape froin these subversive influences impossible.

Furthermore, the same men are obhiged to serve both as prosecutors and as judges. This not only undermines judicial fairness; it weakens public confidence in that fairness. Commission decisions affecting private rights and conduct lie under the suspicion of being rationalizations of the preliminary findings which the commission, in the role of prosecutor, presented to it self [sic]. ${ }^{36}$

It can be argued with some force that the APA was designed to deal with this systemic problem by creating a logical allocation between decisions of will and decisions of logic. The majoritarian decision of will to regulate rates im the railroad industry, for example, should at the minimum allow the affected parties to argue their case to the body pohitic, if not on the broad pohicy question of whether government ratemaking is proper, then at least on the subsidiary question whether a specific rate established by the ICC is reasonable. ${ }^{37}$ What is sometimes not fully recognized is that this pohtical compromise gives only limited protection to the affected private mdividuals. All that the APA was intended to guarantee is a "right" to a "fair" hearing, not a "fair" result. However, by virtue of this right to a hearing the affected parties have the opportunity to fight for a "fair" substantive resnlt before the ICC, a political body with a membership and values shaped by elected presidents, and budgets and substantive pohicies shaped by elected congresses.

One final notion of critical importance to understanding current admimistrative law theory and practice is the concept of independent expertise. ${ }^{38}$ No concept in our constitutional system has been both so

36. Id. at 39-40. It should be noted, however, that the problems of federal bureaucracy antedated the New Deal, as illustrated by J. BECK, OUR WONDERLAND OF BuREAUCRACY (1932).

37. See generally Morgan, Toward a Revised Strategy for Ratemaking, 78 U. ILL. L. F. 21 (1978), for a detailed discussion of ratemaking procedures under the Admimistrative Procedure Act.

38. Agency expertise is generally thought to be applicable to procedural as well as substantive issues. In FCC v. Schreiber, 381 U.S. 279, 290 (1965), Chief Justice Warren referred to "the congressional determination that administrative agencies and administrators will be familiar with the 
important and at the same time so ill thought out over the last halfcentury as the role of the expert in public decisionmaking. We began the modern era with an almost unbounded faith in the ability of scientific and otler kinds of experts to set the world right. Neither the Great War nor the Great Depression shook this faith significantly. The new administrative bodies that sprang up from the teens to the late thirties were evidence of a belief on the part of our society that technical expertise had a critical role to play in administrative decisionmaking. Specialized agencies leaded by single administrators or collegial boards with staffs of technical experts were set up to regulate airlines, communications, foods and drugs, and power facilities. Other expert agencies were thought necessary to deal with securities, monetary policy, labor relations, trade practices, and various other specialized areas. Although the post-World War II era and the advent of nuclear weapons no doubt tarnished society's faith in expertise as an ultinate solution, reliance on experts continued to increase. Product safety, environmental concerns, conimercial nuclear power, commodities markets, automobiles, race relations, workplace conditions, and other areas of significant public concern were all brought within the ambit of the decisionmaking power of expert adiministrative agencies. ${ }^{39}$

But the traumatic social and political events of the last half of the 1960's and first half of the 1970's-Vietnam and Watergate-contributed to a new and more serious reaction against the role of experts, a reaction that formed a part of a larger feeling of distrust of government. The American people began to doubt that expertise alone guaranteed sound social decisions. In fact, experts began to be perceived as part of the

industries which they regulate and will be in a better position than federal courts or Congress itself to design procedural rules adapted to the pecularities of the industry and the tasks of the agency involved." (quoted with approval in Vermont Yankee Nuclear Power Corp. v. Natural Resources Defense Council, 435 U.S. 519, 525 (1978)). See also ATTORNEy GenERAL's CommitTEe on Administrative Procedure, Administrative Procedure in Government Agencies, S. Doc. No. 8, 77th Cong., 1st Sess. 15, 19 (1941).

39. See, e.g., Atomic Energy Act of 1954, ch. 1073, 68 Stat. 919 (amending the Atomic Energy Act of 1946, ch. 724, 60 Stat. 755 and establishing the Atounic Energy Comınission, which was abolished in 1974, at which time most of its functions were transferred to the Nuclear Regulatory Commission, Energy Reorganization Act of 1974, Pub. L. No. 93-438, \$§ 104, 201-209, 88 Stat. 1233, 1237-38, 1242-48); Civil Rights Act of 1957, Pub. L. No. 85-315, 71 Stat. 634 (establishing the Commission on Civil Rights); Civil Rights Act of 1964, Pub. L. No. 83-352, tit. VII, 78 Stat. 241, 253-66 (establishing the Equal Einployment Opportunity Coinınission); Occupational Safety and Health Act of 1970, Pub. L. No. 91-596, 84 Stat. 1590 (establishing the Occupational Safety and Health Review Commission and the National Institute for Occupational Safety and Health); Consuiner Product Safety Act, Pub. L. No. 92-573, 86 Stat. 1207 (1972) (establishing the Consumer Product Safety Coinmission); Commodity Futures Trading Commission Act of 1974, Pub. L. No. 93-463, 88 Stat. 1389. 
problem rather than sources of solutions. ${ }^{40}$ Just as it has been said that war is too important to be left to the generals, significant sectors of the body politic began to suggest that nuclear power was too important to be left to the Nuclear Regulatory Commission, that broadcast license decisions were too important to be left to the Federal Communications Commission, and that pesticide control decisions were too important to be left to the United States Departnent of Agriculture. The response at the political level was not, however, to remove the experts from the decisionmaking process, or even to clarify and define the kind of expert decisionmaking the agencies should freely engage $\mathrm{m}$. In part, this was because our faith $\mathrm{m}$ expertise was and is still quite strong. It was also because the institutional and legislative constituencies for expertise were quite strong and firmly entrenched in the governmental inachine. Thus, instead, the reniedy was to introduce otler parties and other factors into tlie administrative process.

In general, three additional categories of controls were overlaid onto existimg administrative structures, controls not derived froin fundamental due process requirements, but put forward as a means of substantively improving agency decisions. The first of these provided for the involvement of new participants in the inaking and applying of regulations. Expanded standing to challenge rules and rulings ${ }^{41}$ and requirenents for public input and participation in inore and more agency matters ${ }^{42}$ are inamifestations of this trend. Next came a variety of general procedural requirements intended to "open up the process" by creating a kind of general public record. Statutes like the Freedoin of Information Act (FOIA), ${ }^{43}$ the National Environmental Pohicy Act (NEPA), ${ }^{44}$ the Federal Advisory Committee Act (FACA), ${ }^{45}$ the Privacy Act, ${ }^{46}$ the Govern-

40. Cf. C. Cerf \& V. Navasky, The Experts Speak: The Definitive Compendium of AUTHORITATIVE MisINFORMATION (1984) (a humorous collection of expert misinformation on a variety of subjects).

41. See, e.g., United States v. Students Challenging Regulatory Agency Procedures (SCRAP), 412 U.S. 669 (1973); Office of Communication of the United Church of Christ v. FCC, 359 F.2d 994 (D.C. Cir. 1966); see generally StafF of SENATE COMm. on Governmental AfFairs, 95TH ConG., 1st Sess., Study on Federal Regulation vol. III, ch. 3 (Comm. Print 1977).

42. For a discussion of the extent of public participation in regulatory proceedings and of proposals to facilitate public participation, see STAFF of SENATE COMM. ON GOVERNMENTAL AFfairs, 95th Cong., Ist Sess., Study on Federal Regulations, vol. III, ch. 3 (Comm. Primt 1977). See also Stewart \& Sunstein, supra note 2, which is an attenupt to develop a general theory of private rights in public programs.

43. Pub. L. No. 90-23, 81 Stat. 54 (1967) (codified, as amended, at 5 U.S.C. $\S 552$ (1982)).

44. Pub. L. No. $91-190,83$ Stat. 852 (1970) (codified, as amended, at 42 U.S.C. $\S \S 4321-4347$ (1982)).

45. Pub. L. No. $92-463,86$ Stat. 770 (1972) (codified, as amended, at 5 U.S.C. app. $979-86$ (1982)).

46. Pub. L. No. 93-579, 88 Stat. 1896 (1974) (codified, as amended, at 5 U.S.C. $\S 552 \mathrm{a}(1982)$ ). 
Inent in the Sunshine Act, ${ }^{47}$ and the Ethics in Government Act ${ }^{48}$ all have as one of their inain purposes the making available to special interest groups and inembers of the general public alike information tliat would allow them to keep abreast of - and so potentially participate in-the deliberations of the expert bodies. The third and most recent development has been the attempt to craft interbranch controls-general in form, but capable of specific application-over the decisions of the agencies. The legislative veto, ${ }^{49}$ the executive rule review function performed by the Office of Management and Budget (OMB), ${ }^{50}$ and the provisions for expanded judicial scrutmy of agency decisions embodied in the proposed Bumpers ainendinent ${ }^{51}$ are the most important examples of this latter group. In recent years, each of these interbranch control devices has received extensive treatment in legislative hearings, ${ }^{52} \mathrm{~m}$ the law journals, ${ }^{53}$ at specialized conferences, ${ }^{54}$ and in public policy literature generally.

47. Pub. L. No. $94-409$, 90 Stat. 1241 (1976) (codified, as amended, at 5 U.S.C. $\S \S 551-552$, 552b, 556-557, 5 U.S.C. app. $\S 10$ at 983,39 U.S.C. $\S 410$ (1982)).

48. Pub. L. No. 95-521, 92 Stat. 1824 (1978) (codified, as amended, at 2 U.S.C. $\S \S 118 \mathrm{a}, 288-$ $288 \mathrm{~m}, 701-709,5$ U.S.C. $\S 5316,5$ U.S.C. app. at $1005-06,18$ U.S.C. $\$ 207,28$ U.S.C. $\S \S 49$, 528529, 591-598, 1364, 28 U.S.C. app. at 427-35, 39 U.S.C. $\S \S 3210,3216,3219$ (1982)).

49. The Supreme Court held the legislative veto to be uuconstitutional in Immigration \& Naturalization Service v. Chadha, 103 S. Ct. 2764 (1983). For a general discussion of alternatives to the legislative veto, see ADMINISTRATIVE CONFERENCE OF THE U.S., Legislative VeTo of AGENCY RUles After INS v. ChadHa (1984); see also Cong. Res. Service, Studies on the LegislaTIVE Veto (Comm. Print 1980) (studies commissioned by the House Committee on Rules).

50. See Exec. Order No. 12,498, 50 Fed. Reg. 1035 (1985); Exec. Order No. 12,291, 3 C.F.R. 127 (1982), reprinted in 5 U.S.C. $\S 601$ app. at 431-34 (1982).

51. The term "Bumpers amendment" has beeu applied to various forns of legislative proposals that would eliminate any presumptiou of validity of agency rules. See 1 C.F.R. $\S 305.81-2$ (1984) (preamble to Recommendation 81-2 of the Administrative Conference of the U.S., "Current Versions of the Bumpers Amendment"); Levin, Judicial Review and the Bumpers Amendment, in FEDERAl Bar Ass'N, CURRent Issues and Regulatory REForm 264 (M. Rosenberg \& B. McGovern eds. 1980).

52. See, e.g., Office of Management and Budget Control of OSHA Rulemaking, Hearings Before the Subcomm. on Manpower and Housing of the House Comm. on Govt. Operations, 97th Cong., 2d Sess. (1982). Hearings on the legislative veto include Congressional Review of Agency Rules, Hearing Before the Subcomm. on Administrative Practice and Procedure of the Senate Comm. on the Judiciary, 98th Cong., 2d Sess. (1984); Constitutional Amendment to Restore Legislative Veto, Hearing Before the Subcomm on the Constitution of the Senate Comm. on the Judiciary, 98th Cong. 2d Sess. (1984); Legislative Veto After Chadha, Hearings Before the House Comm. on Rules, 98th Cong., 2d Sess. (1984).

53. See, e.g., Bruff \& Gellhorn, Congressional Control of Administrative Regulation: A Study of Legislative Vetoes, 90 HARV. L. REv. 1369 (1977); Levin, Review of "Jurisdictional" Issues Under the Bumpers Amendment, 1983 DUKE L.J. 355; Levinson, Legislative and Executive Veto of Rules of Administrative Agencies: Models and Alternatives, 24 WM. \& MARY L. REV. 79 (1982); Note, The Decline of the One-House Veto after Chadha v. Immigration \& Naturalization Service and Consumer Energy Council of America v. Federal Energy Regulatory Commission, 18 NEw ENG. L. REv. 943 (1983).

54. E.g., Legislative Veto of Agency Rules after INS v. Chadha, agenda item at the TwentySeventh Plenary Session of the Administrative Confereuce of the Umited States, held at Washington, 
There is no reason to rehearse that commentary here. However, it is important to note the collective and cumulative effect that all of these developments-expanded standing and participation, the creation of a general public record, and interbranch controls-have had on the developinent of administrative law, and this aspect of the subject has received surprisingly scant attention.

These various attempts to assert greater control over the agencies are a symptoin that our political system is deeply troubled by the current process by which admimistrative decisions are made. In part, the misgiving is directed at the speciahzed and hence coinpartmentalized nature of current administrative decisionmaking. Decisions that may have an effect upon the whole of society are being made by bodies with an alleged competence in only specialized sectors, ${ }^{55}$ and that alleged competence is, of course, under attack even within the agencies' areas of expert jurisdiction. ${ }^{56}$ The push for greater and inore effective private, legislative, executive, and judicial oversight is also a reflection of a strong feeling on the part of Americans that their government is just too big and too intrusive in an absolute sense. This perception of excessive size and complexity is reinforced by the fact that, whatever the benefits of governmental actions, they are purchased at an extremely high economic and social cost. And, finally, it cannot be doubted that additional controls seem desirable because there is a significant lack of social consensus as to the solutions to the difficult problems facing our society. There is a dehcate balancing of values involved in crafting those solutions. People want safer and cheaper products. They want cleaner air without any loss of jobs in

D.C. (Dec. 15, 1983) (proceedings published by the Administrative Conference, see supra note 49); Conference on the Iinplications of Executive Order 12,291 for Environmental Policy, held at Cliapel Hill, N.C. (Oct. 11-12, 1982).

55. Gerald E. Frug compares the "expertise unodel" of agency operation to that of corporate management: "[J]ust as shareholders can comfortably defer to inanageinent's business judgment concerning the essential issues of corporate governance, citizens can legitimately accept the decisions of a particular government agency on matters within its expertise." Frug, The Ideology of Bureaucracy in American Law, 97 HARv. L. REv. 1277, 1320 (1984).

56. See $1 \mathrm{~K}$. Davis, Administrative Law Treatise $\S \S 2.6,2.13$ (2d ed. 1978); L. Jafre, supra note 30, at 576-85; and Fuller, The Forms and Limits of Adjudication, 92 HARV. L. REV. 353, 372-81 (1978), for examples of the proposition that the application of agency expertise must be overseen by the courts. In discussing "Expert Adminnstration and Democracy," Justice Frankfurter observed that "protection" against abuses of "the power which might more and inore be lodged in administrative experts" inust be both procedural and political:

[W] hile expert administrators may sift out issues, elucidate them, bring the hight of fact and experience to bear upon them, the final determinations of large policy must be made by the direct representatives of the public and not by the experts... . In the final analysis, we are in the realn of judgment regarding values as to which there is as yet no voice of science. The very notion of democracy miplies the right of the public to decide these matters on its own choice.

F. Frankfurter, The Public and Its Government 157-60 (1930). 
heavy industry. They want economic growth, but not industrial or commercial developinent of the areas where they live and play.57 Many of these competing desires can be harmonized by compromise. But very few of them can be resolved in such a way as to satisfy completely all the diverse interests that are implicated. Moreover, at the margins, where most of the critical governmental decisions occur, there is far less chance of harmony. Consequently, there is often a reluctance on the part of the political system - in any of its manifestations-to actually make the difficult decisions.

Against this background, the administrative process in the mid1980's is caught in the following crosscurrents. On the one hand, a deep and real concern witl the way in which administrative decisions are made is felt by the advocates of more governmental intervention. They distrust tlie agencies because they view them as being too concerned with the rights of the private interests that are the object of regulation. ${ }^{58}$ Thinkers of this school find a solution in more regulation and more assurances that the regulators are operating "effectively." On the other hand, an equally deep and real concern is felt by opponents of government intervention, who distrust the agencies because, to these people, the regulatory bodies are too bureaucratic and unresponsive ${ }^{59}$-and sometimes overzealous. ${ }^{60}$ The solution proposed by this second group is to limit the ability of the agencies to impose their view of economic and social reality upon the econoiny and society at large. These diametrically opposed attitudes ${ }^{61}$ converge in a chimerical desire to impose "objective," non-political limits on the administrative system. The goals of

57. Several of these self-contradictory social goals are explored in R. LITAN \& W. NoRDHAUS, REFORMing FeDERAL REgulation 36-58 (1983), reviewed in Diver, Book Review: Regulating the Regulators, 132 U. PA. L. REV. 1243 (1984).

58. See generally P. QUiRK, INdUSTRy INfluence in Federal Regulatory Aguncies (1981), reviewed in 81 MICH. L. REv. 1096 (1983).

59. Bil Gilbert, in Alone in the Wilderness, SPORTS ILLUSTRATED, Oct. 3, 1983, at 96, 102-03, attacks the Bureau of Land Managennent of the Department of the Interior in this vein. Even agency heads have been known to characterize their own organizations as "unresponsive bureaucrac[ies]." See The David Who's Now the TVA Goliath, 10 NAT'L J. 1208 (1978) (remark about the Tennessee Valley Authority (TVA) attributed to S. David Freeman, who had been appointed Chairman of the TVA in May, 1978).

60. "The 1980 FTC authorization included a number of restrictions on the agency. FTC critics said the ineasures were necessary to rein in an overzealous regulatory agency . . . . Supporters of the FTC contended that the agency was simply doing its job of proteeting consumers and counpanies ...." Sarasohn, Action Expected After Elections: Restraints on FTC Extended Pending New Authorization, 40 CONG. Q. WEEKLY REP. 2637 (1982).

61. There is, of course, a "middle ground" that rejects both extremes and argues instead that a certain quality of life needs to be guaranteed by government, and that this should be the proper focus of political thinking. See S. KeLMAN, What Price INCENTIVES? EConomists AND THE ENVIRONMENT (1981). But it is not at all clear that moderate views can prevail in the crossfire generated by the extrene positions. 
either position involve a change in the very reason why the administrative process as we know it developed. The pro-regulatory view seeks to commandeer the process for its own ideological purposes by limiting administrative discretion to the minimuın and making niajor changes in policy direction very difficult. Advocates of deregulation seek to minimize the interventionist damage by erectimg nuinerous hurdles to the process of rulemaking and administrative adjudication. Both goals naturally lead to the one institution most capable of slowing down and restricting administrative action: the court.

Law is restraint. It ultimately operates by force. Although in a healthy and free society a consensus on legitimacy inakes explicit rehance upon force the exception rather than the norm, the use of soine form of sanction-such as the withholding of government benefits-is necessary to make law effective. This necessary operational mode of law defines what law can and what it cannot do. You can do inany things by threat or pronise, but you cannot create or invent by that method. It is undoubtedly true that through threats or promises, creativity and invention can be stimulated, though not in predictable ways. Witness, for example, the creative welfare fraud schenies which have arisen $i 1$ response to those well-intentioned laws, or the nianipulation of grant and tax laws by creative lawyers and accountants to achieve ends never dreamed of by the legislators. A law cannot mandate a work of art, an invention, or a new approach to business or social relationships. Although the law at its best may channel human creativity by restricting soine types of conduct and encouraging and underwriting others, and by reducing the threats to lunian freedoin that may stifle creativity, its essential nature is wonderfully biased to restricting actions. Creativity and invention can spring only from the individual hunan mind, while law operates at the level of society.

In the political branches of government, action usually takes the form of law-rules, orders, decisions, exceptions. The substance of governnient action, lowever, can and often does resenible the actions of a private person. For example, when our government builds a space shuttle, it liarnesses the creative energy of individual scientists, engineers, technicians, administrators, and astronauts in an act of human will and creativity. Statutes, regulations, and even adjudication are involved, but they are not the essence of the act. The courts, however, unlike the executive or legislative branches, can act only within the inode of law. Judicial acts are-or should be-purely legal in character. Thus, while political bodies have the potential to be creative, courts inust always be instruments of restraint. The judicial function begins where the deniocratically-controlled process of policy formation ends. As the monitors 
of internal consistency in matters of interpretation, procedure, and enforcement, the courts can be said to deal exclusively with restricting the end product of the political system, and their decisionmaking apparatus is admirably suited to this task. That apparatus is seriously defective in the sphere of policymaking, just as the art of crafting policy decisions is wholly inconsistent with the function of the court.

While the courtroom may be the stage of history at times, it is no more suited for this role than the battlefield or the convention hall are fit places to try a legal case. Lawyers often want great public debates resolved in the judicial forum: it is exciting and ennobling to the legal profession. But that is not the proper role of the courts, and to the degree that the legal system becomes the arbiter of public policy it fails its umique trust to society. Lawyers, as trustees of our legal system, must not use that system to impose their clients' political will, or their own, on society at large. When they want to play that game they must change roles and do it as policymakers or politicians.

Nevertheless, today we are faced with a governmental system that has greatly overvalued, and hence overemphasized, the kind of decisions that can be made by means of the judicial process-decisions of logic. The einbracing of the judicial model has been to the detriment of the kind of decisions made by individuals possessing adıninistrative discretion derived from a popular or pohtical mandate-decisions of will. This change has come about in part because there has been a failure of confidence in the quahity of government administrators and their administrative decisions. More fundamentally, there has developed a distrust of the political process as a means of making the important decisions affecting our society and our very hives. Reacting against the output of the administrative state, we have been led to believe that the judicial process and its procedures, and their promise of insulation from at least some types of political pressure, are the answer to this crisis of confidence.

The failings of some regulatory and administrative officials, the limited resources of agencies, the slowness of the bureaucratic process, the uncertainties inherent in technical standards and the studies that produced thein, and the conflicts of interest that sometimes seem to affect government fact-finding and policy determinations, all appear, in our current social mythology, to have an appealing solution in the judicial process. ${ }^{62}$ This mythology tends to idealize the independent legal gener-

62. See, eg., Confidence in Institutions, The Gallup RePOR', Oct. 1983, at 3, 3-4, 8 (public confidence in the United States Supreme Court approximately the same in 1983 as in 1973, while confidence in Congress inarkedly declined during the same period); see generally S. LIPSET \& W. SCHNEIDER, THE CONFIDENCE GAP 13-81 (1983). But see Harris, Confidence in Institutions Rises Sharply, THE HARRIS SURVEY, Dec. 17, 1984, at 1, 1-2 (public confidence in the United States 
alist in the black robes as one who always makes objective decisions "on the record" in accordance with a strict protocol designed to ferret out the truth and arrive at a just result. Of course, the very nature of the matters typically brought to the courtroom for resolution, and the way they are structured by the litigation process, go a long way toward assuring a measure of success. We often forget this, however, and assume that the specialized qualities of the judge and the judicial process can be applied in other settings with equally effective results.

And there are other reasons why the judicial model is so alluring. Traditionally, the courts have functioned as protectors of property and due process rights, and this can be expected to lead some to regard them as a primary hine of defense against the interventiomist state. On the other side, pro-regnlation and other constituencies without current political "clout" naturally come to the one non-majoritarian branch of the federal system. Some have seen in contemporary judicial activism a natural extension of the nineteenth-century common law tradition, with current beneficiaries of government prograins the natural heirs of those who used the courts to keep government and private individuals from imfringing upon their hiberty and property. ${ }^{63}$ And, finally, those who still consider expert decisionmaking to be the answer to our social problems find a better model in the professional judge than in the ultra-plurahistic legislative and executive branches. Before looking at alternative ways of dealing with this widespread mistrust of the pohtical decisionmaking process - that is, before considering alternatives to increased judicialization-the concrete operation of the current overvaluation and overemphasis of the judicial decisionınaking model should be examined.

\section{Causes AND EFfects}

We should first note the inany pohitical controls, both formal and informal, that already operate in the administrative system. The various departments, boards, cominissions, committees, administrations, government corporations, offices, conferences, and agencies ${ }^{64}$ are each headed by a politically accountable official reporting to either the President or

Supreme Court was approximately the same in 1984 as in 1983 and 1973; confidence in Congress was approxinately the same in 1983 as in 1974, but increased somewhat between 1983 and 1984, although still below the level associated with the Supreme Court; public confidence in the White House was approximately the same in 1983 as in 1973, but increased dramatically in 1984-so as to surpass the level of confidence in the Court); Field, California Public Has Considerable Doubts About Soundness of State's Judicial System, The CAlIForNia Poll, May 7, 1985, at 1, 1-2.

63. See Stewart \& Sunstein, supra note 2, at 1202-03, 1316-20; Sunstein, In Defense of the Hard Look: Judicial Activism and Administrative Law, 7 HARV. J. L. \& PUB. POL'Y 51 (1984).

64. On the many forms of entities in the executive branch, see Seidman, $A$ Typology of Government, in Federal Reorganization: What Have We Learned? 33 (P. Szanton ed. 1981). 
the Congress. 65 In addition, within these larger units, there are often semi-autonomous divisions that nominally report to the department or agency heads, but also have some independent relationship to the President or the Congress, and sometimes both. ${ }^{66}$ The numerous links with the Office of the President are created and sustained through the chief executive's appoimtinent and reinoval powers, ${ }^{67}$ through various specific statutory provisions, ${ }^{68}$ through various central management officesprincipally the $\mathrm{OMB}^{69}$-and the cabinet and the White House staff. ${ }^{70}$ With respect to the Congress, there are many fornal reporting and oversight relationships ${ }^{71}$ that, as noted in a recent study by Herbert Kaufinan

65. See the discussion of presidential influence over "independent" administrators who receive direct grants of statutory authority in Note, Judicial Review of Administrative Inaction, 83 CoLUM. L. REv. 627, 641 (1983) (observing that typically the president has not been able to effectively deal with agency inaction). The case of a private corporation running a governunent program under the control of Congress rather than the president is discussed in Note, The Constitutionality of Excluding Desegregation from the Legal Services Program, 84 CoLUM. L. REv. 1630 (1984).

66. For example, the Food and Drug Administration and the Social Security Adıninistration are often in direct contact with the Office of the President, even though both are divisions within the Departınent of Health and Human Services. The same observation can be inade about the Federal Bureau of Investigation and the Immigration and Naturalization Service within the Department of Justice, and the Internal Revenue Service within the Treasury Department.

67. The constitutional grant to the executive, U.S. CoNST. art. II, $\S 2, \mathrm{cl} .2$, has been held to be subject to statutory limitations except when "purely executive officers" are involved, Humphrey's Executor v. United States, 295 U.S. 602, 631-32 (1935). Compare Myers v. United States, 272 U.S. 52 (1926) (statutory provision restricting the President's power of reinoval of a postunaster is unconstitutional), with Humphrey's Executor v. Uinited States, 295 U.S. 602, 629 (1935) (a Federal Trade Commissioner, as a inember of a "quasi-legislative or quasi-judicial" body created by Congress, cannot be removed without cause before the expiration of his term), and Wiener v. United States, 357 U.S. 349 (1958) (same rcasoning applied to a inember of War Claims Coinınission).

68. Sec, for example, the discretion allowed the President in acting on the findings and recommendations of the International Trade Commission in the area of "import rehef," 19 U.S.C.A. $\S \S$ 2251-2253 (1980 \& Supp. 1985)-a discretion which the statute purports to subject to a form of legislative veto, see id. at $\S 2252$ (c). See also 42 U.S.C. $\$ 2155(b)$ (1982) (presidential authority to override a decision by the Nuclear Regulatory Commission on the granting of a special export liceuse, subjeet to legislative veto by concurrent resolution).

69. See, eg., Exee. Order No. 12,498, 50 Fed. Reg. 1035 (1985); Exec. Order No. 12,291, 3 C.F.R. 127 (1982); Controlling Paperwork Burdens on the Public, 5 C.F.R. pt. 1320 (1985) (OMB regulations on the collection of information by federal agencies from individuals, businesses and other private institutions, and state and local governments, issued pursuant to the Paperwork Reduction Act of 1980, 44 U.S.C. $\$ \S 3501-3520$ (1982)).

70. This area has been the subjeet of considerable controversy. See Strauss, The Place of Agencies in Government: Separation of Powers and the Fourth Branch, 84 CoLUM. L. REv. 573, 657-60 (1984) (discussion of "the conduit problem"). The Administrative Conference of the United States has recommended that White House control be made more acceptable by placing "inaterial factual information" contained in intragovernmental communications "in the public file" of an affected rulemaking proceeding. 1 C.F.R. $\S 305.80-6$ (1985).

71. For example, "[i]n the Ninety-fifth Congress, . . . FDA representatives appeared before a total of thirty-two congressional bodies . . . eighty-five times in all." H. KAUFMAN, THE ADMINIStrative Behavior of Federal Bureau Chiefs 48 (1981). 
published by the Brookings Institution, are manifestations of a far more pervasive influence:

At the center of the pattern of relationships for all the [executive branch bureau] chiefs was Congress-its members, collectively and individually, its committees, its staffs, its evaluative arms (the General Accounting Office im particular). This set of congressional and congressionally related workers in the machinery of government seemed rarely to be out of the admimistrators' consciousness. The chiefs were constantly looking over their shoulders, as it were, at the elements of the legislative establishment relevant to their agencies-taking stock of moods and attitudes, estimating reactions to contemplated decisions and actions, trying to prevent imsunderstandimgs and avoidable conflicts, and planning responses when storm warnings appeared on the lorizon. Not that cues and signals from Capitol Hill liad to be ferreted out; the denizens of the Hill were not shy about issuing suggestions, requests, demands, directives, and pronouncements. ${ }^{72}$

Thus, there is an abundance of both formal and actual controls and influences upon the administrative process deriving from the two branclies of the federal government that liave a popular mandate. To the extent that this collection of influences is to be criticized, the criticism must go to the heart of democratic theory, not just to the administrative process. If democracy means anything, it must mean that the majority's "whims" do control policy within the broad limits set by basic constitutional safeguards. To tlie extent that the political branches are effective in translating the majority's wlimis imto pohicy, a critique of tlie results must be directed against the substance of the majority's social priorities or against the way our Constitution embodies democracy.

Given these existing political controls, it is iromc that most of the thrust toward judicialization has come from the political branclies. Over the last generation Congress lias made the imternal processes of administrative decisionmaking less and less discretionary, and more and more formal. ${ }^{73}$ Various types of judicially enforceable "rights" related to the administrative process have been created. These procedural provisions have not ouly benefited the due process interests of the regulated, but also given special interest groups the power to significantly influence regulatory agendas, often in the face of opposition from botli the regulated and the regulators. ${ }^{74}$ Congressional action directed against specific property interests and against the institutional power of the executive brancli should not be surprising; that is the way the Framers believed our polit-

72. Id. at 47.

73. The many "hybrid" rulemaking statutes enacted from 1969 to 1981 are described in ADMinistrative Conference of the U.S., A Guide to Federal Agency Rulemaking 65-71 (1983).

74. See Sunstein, Deregulation and the Hard-Look Doctrine, 1983 SuP. CT. REv. 177, 177-87. 
ical system would work, given human nature. ${ }^{75}$ What is surprisingand, I would argue, counterproductive-is that the recent approach to government decisionmaking adopted by Congress has resulted in the augmenting of the institutional power of the third branch and, therefore, of those special interests with the capacity to use the courts to achieve judicially what they could not obtain potitically. ${ }^{76}$

75. Alexander Hamilton, writing on the need for "maintaining in practice the necessary partition of power aunong the several departments" of the national government, urged that

the great security against a gradual concentration of the several powers in the sane department, consists im giving to those who administer each department, the necessary constitutional means, and personal motives, to resist encroachments of the others. The provision for defence must in this, as in all other cases, be made commensurate to the danger of attack. Ambition must be made to counteract aunbition. . . . It may be a reflection on human nature, that such devices should be necessary to control the abuses of government. But what is government itself, but the greatest of all reflections on human nature? If men were angels, no government would be necessary. If angels were to govern men, neither external nor internal controls on government would be necessary.

THE FEDERALIST No. 51. Hamilton also thought the saine general approach could "guard one part of society against the injustice of the other part," "by comprehending in the society so many separate descriptions of citizens, as will render an unjust combination of a inajority of the whole very improbable, if not impracticable." Id. See also THE FEDERALIST No. 48 (J. Madison) (the separation of powers doctrine in practice).

76. Recently the Umited States Supreme Court decided Heckler v. Chaney, 53 U.S.L.W. 4385 (U.S. Mar. 20, 1985). This case, with its rather bizarre fact pattern, did not involve a special procedural statute, but it does present a classic illustration of judicialization's deleterious effects. The suit was brought by death row inmates secking to have the Food and Drug Admimistration (FDA) prevent the states of Oklahoma and Texas from using certain injectible drugs to carry out death sentences. The inmates "claimed that the FDA was required [under provisions of the Food, Drug, and Cosmetic Act, 21 U.S.C. $\$ \S 352(f), 355$ (1982)] to approve the drugs as 'safe and effective' for human execution before they could be distributed im interstate commerce," id. at 4385 . The prisoners received a favorable decision in the Court of Appeals for the District of Columbia Circuit, thus using a statute passed to protect public health to temporarily stave off executions decreed in thc interests of public safety. This is surely one of the more extreme exaunples of "rights" created by a regulatory statute being used against the regulator, the regulatee, and the public interest. The notion that both the regulating agency and the object of regulation are somehow unable or unwilling to bring such a case before the judiciary when necessary produces this bizarre designation of death row inmates as the true representatives of the public interest!

The Chaney case is notable not ouly as an extreme exanple of the judicialization of the adininistrative process, but also because of the Supreme Court's reversal of the court of appeals. The Court said that the case turned upon "the extent to which determinations by the FDA not to exercise its enforcement authority over the use of drugs in interstate commerce may be judicially reviewed," 53 U.S.L.W. at 4386 (emphasis in original), and went on to find that section 701(a)(2) of the APA contains a presumption that agency decisions not to institute enforcement proceedings are unreviewable, and that the presumption was not overcome in this case, id. at 4389 . An indication that an even broader change in philosophy may radiate from thc core of this case is found in the opinion's comment that "[i]n addition to . . . admimistrative concerns, we note that when an agency refuses to act it generally does not exercise its coercive power over an individual's liberty or property rights, and thus does not infringe upon areas that courts often are called upon to protect." Id. at 4387-88 (emphasis in original). This general approach indicates a sense of the role of courts as guardians against abuses of the adıministrative process, rather than as participants in that process. But $c f . i d$. at 4394 (Marshall, J., concurring in the judgunent) ("The problem of agency refusal to act is one of the pressing problems of the inodern administrative state, given the enonnous powers, for both good and ill, that agency inaction, like agency action, holds over citizens. . . . Because the Court's approach, 
Similarly, although in theory the numerous legislative veto provisions enacted over the last several decades aimed at review of the adininistrative process by a decision of pohtical will, their practical effect was to create another procedural level: appeal froin agency decisionmaking to the staffs of congressional committees. ${ }^{77}$ And the vague statutory inandates inade pohtically possible by the reassuring presence of the legislative vetoes invited the kind of judicial "supervision" of agency pohcy and direction associated with over-broad grants of power. ${ }^{78}$ These new levels and kinds of appeals have had the effect of further reducing agency discretion. The agencies were thereby further constrained by outside forces, without gaiming much additional regular, coherent, and politically responsible policy input. In this sense, the Supreine Court's 1983 decision in Immigration \& Naturalization Service v. Chadha ${ }^{79}$ represents a surprising inovement away froin judicialization, ${ }^{80}$ and may result in soine simphification of the administrative process. The decision eliminated a vague set of review structures that may well be replaced by true congressional policy oversight, ${ }^{81}$ if some of the proposals introduced into Congress soon after Chadha was handed down ${ }^{82}$ really reflect a new concern in

if taken literally, would take tlie courts out of the role of reviewing agency inaction in far too many cases, I join only the judgment today.")

Moreover, Justice Rehnquist, writing for the majority, noted in a concluding dictum that

The fact that the drugs involved in this case are ultimately to be used in imposing the death penalty must not lead this Court or otlier courts to import profound differences of opinion over the meaning of the Eiglith Amendment to tle United States Constitution into tlie dounain of administrative law.

Id. at 4389.

77. For a discussion of the constitutional, statutory, and policy issues raised by the legislative veto of agency rulemaking, see Bruff \& Gellhorn, supra note 53, at 1372-81.

78. Cf., e.g., Calvert Cliff'' Coordinating Comm. v. Atomic Energy Comm'n, 449 F.2d 1109, 1112, 1122 (D.C. Cir. 1971) (construing the "broad" and "flexible" policy enunciated in the National Environmental Policy Act, 42 U.S.C. $\$ \S 4321-4347$ (1982)); infra notes 83-98 and accompanying text.

79. 103 S. Ct. 2764 (1983).

80. An argument ean also be inade to the contrary that, insofar as the legislative veto did serve a useful function, Chadha is yet another example of judicialization, removing what slould be decisions of will from the political branches. There is undoubtedly some validity in this view. To the extent that Chadha is a complex case with potential apphication to a highly diverse set of laws and administrative contexts, it is difficult to cliaracterize it broadly as either a pro- or an anti-judicialization development. I am indebted to Mr. Thomas M. Susınan for his perceptive thoughts on this point.

81. "True congressional policy oversight" ineans the formulation and subsequent adjustinent of policy, not the reversal of particular executive decisions or the review of the minutiae of adninistrative regulations and procedures.

82. E.g., H.R. 3939, 98th Cong., 2d Sess. (1983) ("To amend title 5, Umited States Code, and the Rules of the House of Representatives and the Senate, to make regulations more cost-effective, to ensure review of rules, to improve regulatory planning and management, to provide for periodic review of regulations, and to enhance public participation in and congressional oversight and control of the regulatory process . . . ."); S. 1080, 98th Cong., 1st Sess. $§ 13,129$ CoNG. REc. S17,081 (daily ed. Nov. 18, 1983) (providing for congressional review of agency ruleınaking). A more recent 
Congress with the administrative process.

But neither the additional procedural legislation enacted in recent decades, nor the pre-Chadha legislative vetoes can account, by themselves, for the full strength of the trend toward judicially modeled formalization. Perhaps the most important way in which Congress itself has contributed to the limiting of agency discretion and the judicialization of the administrative process has been the granting of broad substantive mandates to the agencies to fulfill their statutory purposes. This seems like a paradoxical if not absurd statement. How can broad mandates lead to a narrowing of real agency discretion? The answer is not as subtle as inight be imagined. Judicial review becomes far more important in defining the direction and meaning of a statute when that statute sets out vague and possibly self-contradictory mandates to an agency, rather than clear or simple directives that leave little room for any judicial doubt as to the agency's imission. ${ }^{83}$ Under a broad mandate, and in the absence of ongoing congressional policy oversight, the courts become the arbiters not only of claims by individuals agamst the agencies, but of agency policy direction as well..$^{84}$ The well-known case of Motor Vehicle Manufacturers Association v. State Farm Mutual Automobile Insurance Co. ${ }^{85}$ provides a good example of just low this can occur.

State Farm imvolved a cliallenge to the rescission of a regulation previously issued under the National Traffic and Motor Velicle Safety Act of 1966.86 The regulation had required the use of automatic crash protection devices-airbags or "passive" seatbelts-in motor vehicles manufactured after a certain date. It was alleged that the reversal of this policy under the Reagan administration was unsupported by the data available to the responsible agency and inconsistent with the purpose of the enabling statute. In defining its scope of review, the Supreme Court described the statutory basis of the controversy.

The Act, created for the purpose of "reduc[ing] traffic accidents and deaths and injuries to persons resulting froin traffic accidents,"... directs the Secretary of Transportation or his delegate [the National Highway Traffic Safety Administration (NHTSA)] to issue motor vehicle safety standards, that "shall be practicable, shall ineet the need for inotor vehicle safety, and shall be stated in objective terms."

example is S. 1145, 99th Cong., 1st Sess., 131 CoNG. REc. S6267 (daily ed. May 15, 1985) ("To imcrease the accountability of, policy coordination by, and management of priorities by agencies through an improved meclianism for congressional oversiglit of the rules of agencies.").

83. See Scalia, supra note 3 , at 382 .

84. See, e.g., Calvert Cliff' Coordinating Comm. v. Atomic Energy Comm'n, 449 F.2d 1109, 1111-12, 1115-16 (D.C. Cir. 1971).

85. 103 S. Ct. 2856 (1983).

86. 15 U.S.C. §§ 1381-1431 (1982). 
... In issuing these standards, the Secretary is directed to consider "relevant available motor vehicle safety data," whether the proposed standard "is reasonable, practicable and appropriate" for the particular type of motor vehicle, and the "extent to which such standards will contribute to carrying out the purposes" of the Act. ${ }^{87}$

The criteria the statute establishes for the guidance of the Secretary and the NHTSA are obviously very broad, and do not provide any clear basis for objective substantive review. Rather, they endorse the type of discretion normally given to an expert. It is not unreasonable in this context for one policy expert to disagree with another. Nor would it be inappropriate for one political official to second-guess another. As a result of debate sparked by such disagreement, a legislative reversal of an administrative judgment in this kind of situation is tlie very stuff of democracy. The substantive issue underlying the procedural dispute decided in State Farm was, after all, a classic political controversy, ${ }^{88}$ and in fact the litigants in the case included those interest groups that would be expected to make their concerns known to their elected representatives and so bring their "case" before the legislative forum. When, therefore, a properly delegated pohicy decision of this sort is effectively reversed by a supposedly non-pohtical entity, which necessarily purports to have no policy preference other than the carrying out of a statutory program, questions naturally arise as to whether the judicial branch is assuming a monitoring function with respect to substantive pohicy, and on what basis it could possibly assume that role.

The Supreme Court was sensitive enough to this concern to note that the "scope of review under the 'arbitrary and capricious' standard is narrow and a court is not to substitute its judgment for that of the agency,"89 and it chastized the Court of Appeals for the District of Columbia Circuit for the latter's "misguided" analysis that had derived froni certain inconclusive legislative events a heightened standard of review of the agency's action. ${ }^{90}$ Nevertheless, the Supreme Court itself found the NHTSA's rescission to be "arbitrary and capricious," at least in form, because all aspects of the rationale of the prior policy had not, in the Court's view, been adequately dealt with in the explanation of the new one. ${ }^{91}$ The Court focused on the lack of internal consistency in the implementation of the statute generated by the NHTSA's stated reasons for its rescission of the automatic occupant restraint regulation, as if the

87. $103 \mathrm{~S}$. Ct. at 2862 (citations and footnote omitted).

88. This aspect of the case is acknowledged in Justice Rehnquist's dissent, see infra note 96.

89. 103 S. Ct. at 2866 .

90. Id. at 2867.

91. Id. at 2868 . 
Administration was not fully aware that it was overturning the previous policy.

The "arbitrary and capricious" standard on its face seems extremely deferential, ${ }^{92}$ but as applied, especially with reference to an administrative judgment made under an extremely broad statutory mandate, it has the potential to convert a procedural review into at least temporary control over substantive policy. Asking whetler the agency "examine[d] the relevant data and articulate[d] a satisfactory explanation for its action"93 is itself so broad a standard that it can be used not only to overturn egregiously arbitary acts, but also to intrnde into the realm of legitimate discretionary agency decisionmaking. There is no briglit line between a judicial cliallenge to an agency's reasoning-given that the agency does not purport to be engaged in a decision of logic-and a court's "substitut[ion of] its judgment for that of tlie agency." 94 In State Farm, the objections to the NHTSA's "explanation" smack of the review nornally exercised by a superior over a subordinate in a bureaucratic hierarcliy. Our constitutional systein liolds higli the notion of the supremacy of the law, but it never has conteinplated the supremacy of the courts in a bureaucratic sense.

The ultimate result of the State Farm litigation was the proinulgation of a new rule that extended until the late 1980's the deadline for installation of automatic occupant restraints in all new cars, and provided for an alternative approach based on the sufficiently widespread use of regular seatbelts enforced under state law. ${ }^{95}$ But in the interim,

\footnotetext{
92. [T] he agency must examine the relevant data and articulate a satisfactory explanation for its action imcluding a "rational connection between the facts found and the choice made." Burlington Truck Lines v. United States, 371 U.S. 156, 168 . . (1962). In reviewing that explanation, we must "consider whether the decision was based on a consideration of the relevant factors and whether there has been a clear error of judgment." Bowman Transp. Inc. v. Arkansas-Best Freight System, [419 U.S. 281, 285 (1974);] Citizens to Preserve Overton Park v. Volpe [401 U.S. 402, 416 (1971)]. Normally, an agency rule would be arbitrary and capricious if the agency has rehed on factors which Congress has not intended it to consider, entirely failed to consider an important aspect of the problem, offered an explanation for its decision that runs counter to the evidence before the agency, or is so implausible that it could not be ascribed to a difference in view or the product of agency expertise.
}

$103 \mathrm{~S}$. Ct. at $2866-67$.

93. Id. at 2866 .

94. Id.

95. The Supreine Court's opinion in State Farm was handed down on June 24, 1983. On Septeunber 1, 1983, the Department of Transportation (DOT) suspended the automatic restraint requirement for one year, 48 Fed. Reg. 39,908 (1983). After careful study and two public comment periods, the DOT issued a final rule in July, 1984 requiring "installation of automatic restraints in all new cars beginning with nodel year 1990 (Septeinber 1, 1989) [subjeet to a phase-in over a three-year period beginning with inodel year 1987] unless, prior to that time, state mandatory belt usage laws are enacted that cover at least two-thirds of the U.S. population." 49 Fed. Reg. 28,962, 28,962 (1984) (to be codified at 49 C.F.R. pt. 571). 
the courts were used to reverse a considered decision of will.96 This is not to say that the judicial branch as a whole has purposefully cast itself in the role of arbiter of pohicy. However, State Farm and other cases in the same vein contribute to the widespread notion that such matters as the appropriateness of motor vehicle occupant safety devices are best determined in accordance with a model based on the judicial process.

The grant of a large measure of agency discretion-such as that contained in the National Traffic and Motor Vehicle Safety Act-is one of those familiar two-edged swords. On the one hand, insofar as a statute does not circumscribe implementation pohicy by means of specific provisions, it can be inferred that Congress contemplated an extremely flexible ongoing policy decisionmaking process, relying primarily-in the absence of subsequent legislation-on those formal and informal controls and influences enianating from the political branches to monitor and delimit agency action; on the other hand, there exists an active piece of legislation that the courts feel an obligation to protect from de facto repeal by the executive branch. ${ }^{97}$ A vacuum is created by this sort of legislative approach, and it is into this vacuum that the judicial apparatus naturally rushes, substituting its procedures for decisions of will, but in the process unavoidably making a form of policy "judgment" as well.

Why are so many of our economic, health, safety, and welfare statutes - the staple of the administrative state-written in this way? Why doesn't the Congress seek to avoid the inevitable administrative law problems that materialize in the vacuums it creates by overly broad delegation? It might well be that the legislature, like other sectors of our society, has succumbed to the paralysis of political will niade possible by the judicial alternative. Facing the considerable and often notorious diffculties of hammering out in statutory form a substantive compromise on a crucial social issue, ${ }^{98}$ the path of least resistance presents an attractive, often irresistible alternative. The legislator's own political future and interests argue against firm pohicy decisions. In setting auto safety stan-

On the day the rule was announced, but prior to its publication in the Federal Register, a suit was filed cliallenging certain provisions of the rule as well as the DOT's autliority to promulgate it. State Farm Mut. Auto. Ins. Co. v. Dole, No. 84-1301 (D. C. Cir. July 11, 1984). This case has been briefed and argued, but no decision lias been rendered.

96. Cf. State Farm, $103 \mathrm{~S}$. Ct. at 2875 (Rehnquist, J., concurring in part and dissenting in part) ("A change in administration brought about by the people casting their votes is a perfectly reasouable basis for an executive agency's reappraisal of the costs and benefits of its programs and regulations.").

97. Cf. id. at 2875 n.* ("Of course, a new administratiou may not choose not to enforce laws of which it does not approve, or to iguore statutory standards in carrying out its regulatory functions. But in this case, . . . Congress lias not required tlie agency to require passive restraints.").

98. See generally Easterbrook, What's Wrong with Congress?, AtLantic Monthly, Dec. 1984 , at 57. 
dards there are powerful pohtical interests-auto manufacturers, unions, insurance companies, consumer activists, importers-that will be angered by whatever standard is set. However, a procedural decision that gives everybody "rights" in the "process" draws attention and anger away from the legislator, and nay indeed make the legislator seem like a friend to all. Thus it is that we nay have reached the poimt where the decisionmaking vacuum, routinely filled by judicial process, is exerting a self-perpetuating attraction all its own.

Of course, passing along the "hard" decisions to the agencies does not end the inatter, as State Farm and many other similar cases demonstrate. The courts, themselves constrained by both constitutional imperatives and their own view of decisionmaking, apply a "hard look" to those "hard" decisions made by agencies, and this leads to unfortunate intrusions into the essentially political domain of the agencies and their missions. Thus we are brought back to the central dilenma confronting present-day administrative law. We have established administrative agencies with technical expertise and a coherence of vision on specific problems. However, when they come up with decisions significant elements of the society do not like, we shift the decisions to judicial bodies, the structure and function of which is based upon premises dianetrically opposed to the theories upon which the administrative agencies were created. The review and, in some instances, the reversal of those administrative decisions are thereby accomplished in ways that tend to undermine the conceptual basis of government regulation in our modern administrative state. And, most importantly, as a result of such political decisionmaking by default, we delude ourselves that we have been spared from having to confront the need for decisions of will.

\section{A NEW DAY?}

The causes of judicialization obviously run deeper than the mere identity of the decisionmakers our society is willing to acknowledge. Even if today there is less distrust generally of the federal bench than of the leadership of the agencies, that alone cannot account for the widespread adoption of an approach to public decisionmaking that is foreign -if not hostile - to the political process. Accordingly, the cure for the systemic dysfunction is not a simple matter of staffing choices and policies. Indeed, judicialization can be viewed as syınptonatic of an even inore fundainental issue, one that goes beyond a choice of decisionmaking methodologies. Perhaps our polity senses that it is not flawed regulation that is bad, but that the very concept of regulation, on the scale we practice it, is flawed. 
In the first quarter of this century, relativity theory and quantum mechanics rapidly displaced classical physics because the classical world view was seriously flawed. ${ }^{99}$ It did not provide a coherent explanation of reality. Certain observational evidence could only be explained by the new theories, which were radically inconsistent witl the old ones; this clash of ideas caused the old paradigm to disintegrate and make room for a new way of seemg the world. The last fifty years of government administration have presented administrative law theory with a similar type of irresistible intellectual pressure. We do not have any coherent justification for the administrative process we confront every day. Legislators and the courts continually fashion new procedural rights, processes, and theories of review applicable to administrative decisionmaking. Virtually every imagimable administrative system can be found embodied in soine governmental structure. The effect of independent agency status, technical expertise, judicial review, notice and cominent rulemaking, and public disclosure on the actual processes of government are debated witl little agreeinent even as to the premises of the discussion. Indeed, it miglit be more accurate to analogize current administrative law theory not to classical physics, but to alcheiny or astrology! I beheve it is time to reexamine the preimses of the administrative, interventiomist state, and to do so from all of the points of view on the political spectrum. Radical thoughts are needed from conservative thinkers, and libertarian analyses from liberals.

In order for this self-examination and analysis to be a fruitful intellectual exercise with the potential to resliape our governmental system in a positive way, it inust focus on several fundamental issues that liave come to be regarded as somewliat unfashionable topics for serious intellectual exploration. ${ }^{100}$ Let ine suggest three. First, some lines inust be drawn to define what is an appropriate governmental function and what is not. If administrative law is to be something other than the handmaiden of the ominipresent state, we must ask in a principled ratlier than an ad hoc way what are the proper boundaries of governmental power. A second and obviously related question has to do with the "rights" of the citizen with reference to the processes of government. To what extent slould there be differences between the plethora of legislatively and judicially generated private interests, rights of action, beneficiary claims, and agency procedural requirements on the one hand, and the tradition-

99. See generally J. Gribbin, In Search of Schrödinger's Cat: Quantum Physics aNd REALITY 19-122 (1984).

100. There are some notable exceptions to this trend: for example, R. BERGER, GovERNMENT By Judiciary: The TRANSformation of THE Fourteenth AMENDMENT (1977); Stewart \& Sunstein, supra note 2; Strauss, supra note 70. 
ally recognized rights enanating froin the Constitution and the common law on the other? And the third question has to do with the increasing commingling of functions ainong the three branches of the federal government. This commingling has appeared in various forms, alınost all of which have involved the burgeoning administrative process: the regulatory role of the executive branch; the creation of the independent agencies; the highly detailed nature of soine nodern legislation-coexisting with broad and amorphous grants of delegated power in other statutes; the ombudsinan-like role adopted by many representatives and senators; the growth of an enormous administrative judiciary in the executive branch; and the increasingly significant effect that federal judicial decisions are having on both individual interests and social policy. We need to ask, then, does the tripartite scheme of powers established by the Framers in 1787 need fundamental reform - or fundamental restoration - in light of the development of the administrative state over the last fifty years? ${ }^{101}$

These radical questions will require both an intellectual and a political debate for their resolution. This will occur not simply because it is intellectually stimulating or because admimstrative law specialists think it worthwhile, but because very real problems of liberty, meaningful justice, and efficiency arise daily within the existing adininistrative law framework. In spite of significant and positive efforts in the direction of regulatory reform, ${ }^{102}$ the administrative state is creatimg rather than solving social and economic problems. It has created unrealistic expectations in the health, safety, and welfare area that have put an unacceptable stram on the legitimacy of law, and this is a danger that is of incalculable magnitude to any free society. The current system is not functioning properly and the dysfunction is growing. Fundainental issues need to be debated because the existing theories underlying administrative law no longer provide a coherent answer to these problems, or even a general sense of direction toward their solution.

101. Cf. Strauss, supra note 70, at 667 (concluding that we must "give up the notion that [the Constitution] embodies a neat division of all government into three separate branches, each endowed with a unique portion of governmental power and employing no other").

102. E.g., Civil Aeronauties Board Sunset Act of 1984, Pub. L. No. 98-443, 98 Stat. 1703 (amending the Federal Aviation Act of 1958, Pub. L. No. 85-726, 72 Stat. 731, to terminate certain functions of the Civil Aeronautics Board and transfer certain functions of the Board to the Department of Transportation); Paperwork Reduction Act of 1980, Pub. L. No. 96-511, 94 Stat. 2812 (codified, as amended, at 44 U.S.C. $\S \S 2904-2905,3501-3520$, S U.S.C. $\S 5315,20$ U.S.C. $\S 1221-3$, 30 U.S.C. 1211, 42 U.S.C. 292h (1982)); Airline Deregulation Act of 1978, Pub. L. 95-504, 92 Stat. 1705 (codified, as amended, in scattered sections of 49 U.S.C. app. and at 18 U.S.C. $\S \S 112,878$, 1116,1201 (1982)) (designed to encourage an air transportation system which relies on competitive market forces); Exec. Order No. 12,498, 50 Fed. Reg. 1035 (1985); Exec. Order No. 12,291, 3 C.F.R. 127 (1982); Exec. Order No. 12,174, 3 C.F.R. 462 (1980). 
Such basic questions-the scope of governmental action; the nature and extent of individual rights to be protected in the face of such action; and the need to sort out anew the separate powers granted to the three branches of the federal government-can hardly be addressed adequately here, but there may be some value in considering how answers to them might give rise to some possible alternatives to the continuing judicialization of the administrative process. In order to do this, it is useful to consider judicialization in terins of its three primary manifestations, mentioned at the beginning of this essay: overproceduralization of governmental processes, excessive rehance upon trial-type procedures in non-judicial settings, and intrusive judicial review of agency actions.

\section{A. Overproceduralization.}

Overproceduralization is the aspect of judicialization inost readily perceived as an evil in the pohtical systen. It has long been a whipping boy; politicians, writers, and the man on the street traditionally have inveighed against bureaucrats, tangles of red tape, and governmental delay and waste. The causes of this phenomenon are not, however, to be found in the penchant of "pointy-headed" bureaucrats for thwarting the public in a Kafkaesque world. I would argue that its primary cause is an attempt by government to do too inuch. This overreaching in terins of the overall scope of governmental functions inevitably leads to specific overloads in the system. There is, first, over-extension of the individual agencies charged with the expansive functions. ${ }^{103}$ When agencies attempt to accomphish impossible tasks or tasks beyond the political or financial resources available to them, their institutional structures are subjected to enorinous strain. The most basic defense mechanism such an organization has is to msulate itself from controversial substantive decisions with layers of procedure, quasi-judicial appeal boards, and highly coinplex regulatory codes.

The expansion of government prograins into inore and more substantive areas has also resulted in an understanding of due process alien to the franiers of either the fiftl or the fourteenth amendinents, and this in turn produces overproceduralization. Since Goldberg v. Kelly ${ }^{104}$ we have embraced an increasingly abstract conception of due process. The

103. Examples include the Social Security Administration and its disability program, the Immigration and Naturalization Service and its border patrol responsibility, the Occupational Health and Safety Administration's statutory mandate, and the Departmeut of Agriculture and its farm subsidy mission.

104. 397 U.S. 254 (1970). See Friendly, "Some Kind of Hearing," 123 U. PA. L. REv. 1267, 1268, 1273, 1299-1300 (1975). The latest expansion of this version of due process is seen in Cleveland Bd. of Educ. v. Loudermill, 53 U.S.L.W. 4306 (U.S. Mar. 19, 1985). 
right to a more or less formalized hearing has come to be held as an article of faith. This is not a necessary implication of the Constitution's mandate of due process. It has become a legal and judicial dogma that fundamental fairness to participants can only be aclieved through the use of hearings with guaranteed procedural steps. While there is an overwhelmingly convincing historical and moral argument for this view in the area where the state seeks to impose criminal sanctions, the proposition is subject to serious question when grants of government benefits are involved. The contemporary inoveinent of the law away from the traditional dichotomy between rights and privileges ${ }^{105}$ has liad the effect of ossifying administrative structures. It causes these structures to be progressively less responsive to the needs which they were created to ad-

105. Compare Cafeteria \& Restaurant Workers Union, Local 473 v. McElroy, 367 U.S. 886, 895 (1961) ("The very nature of due process negates any concept of inflexible procedures universally applicable . . . [C]onsideration of what procedures due process nay require . . . must begin with a determination of the precise nature of the government function involved as well as of the private interest that lias been affected by governmental action. Where it lias been possible to characterize that private interest (perhaps in oversimplification) as a niere privilege subject to the Executive's pleuary power, it has traditionally been held that notice and liearing are not constitutionally required" (footnote omitted)), and United States ex rel. Knauff v. Shaughnessy, 338 U.S. 537, 542 (1950) ("[a]dmission of aliens to the United States is a privilege" to be "granted . . . only upon such terms as the United States slall prescribe"), with Goldberg v. Kelly, 397 U.S. 254, 262 (1970) (welfare benefits are "a matter of statutory entitlenient for persons qualified to receive then" and a constitutional clallenge to termination procedures "cannot be answered by an argunient that public assistance benefits are "a "privilege" and not a "right" ' " (quoting Shapiro v. Thompson, 394 U.S. 618, 627 n.6 (1969) and citing illustrative cases) (footnote omitted)), and Dixon v. Alabama State Bd. of Educ., 294 F.2d 150, 156 (5th Cir.), cert. denied, 368 U.S. 930 (1961) ("It is not enough to say, as did the district court in the present case, 'The right to attend a public college or university is not in and of itself a constitutional right.' "). But see Snolla, The Reemergence of the Right-Privilege Distinction in Constitutional Law: The Price of Protesting Too Much, 35 STAN. L. REv. 69,69 (1982) (reviewing post-Goldberg $v$. Kelly cases, especially those based on an "entitlenient theory," and concluding that, "like the prenaturely mmored death of Mark Twain, . . . reports of the demise of the privilege doctrine have been greatly exaggerated").

It is possible to object to the due process developnents exemplified by Goldberg v. Kelly and yet be concerned that the distinction between "rights" and "privileges" not be misused in sucl a way as to allow the government to condition its largesse on the giving up of substantive constitutional rights and so accomplish-at least with respect to compliant beneficiaries-indirectly what it is forbidden to do directly. On the latter ponit, see Van Alstyne, The Demise of the Right-Privilege Distinction in Constitutional Law, 81 HARv. L. REv. 1439, $1445-49$ (1968). But there is no self-contradiction in such a view. The real problen, as Justice Rehnquist noted in his dissent in Cleveland Bd, of Educ. v. Loudermill, 53 U.S.L.W. 4306, 4314 (U.S. Mar. 19, 1985), is that these cases represent

an ad hoc weighing which depends to a great extent upon low the Court subjectively views the underlying interests at stake. The results . . . lave been quite unpredictable. . . . The lack of any principled standards in this area nieans that these procedural due process cases will recur time and again. Every different set of facts will present a new issue on what process was due and when. One way to avoid this subjective and varying interpretation of the Due Process Clause in cases such as this is to lold that one who avails himself of government entitlements accepts the grant of tenure along with its inherent linitations.

See also Amett v. Kennedy, 416 U.S. 134, 152-54 (1974) (Rehnquist, J., plurality opinion) (genesis of the now discredited "bitter with the sweet" approach, see Loudermill, 53 U.S.L.W. at 4308). 
that has contributed to the current excessive rehance on them. From the medieval trials by combat or compurgation to our most complex modern federal civil hitigation, there is an unspoken belief in the "trial" as the best means of "settling" certain kinds of disputed fundamental questions. One's "day in court" is sucl an appealing slogan because it implies a quick, decisive, and final result. The idealized trial embodies all the favorable connotations of this concept. Unfortunately, the reality is somewhat different, especially in the area of admimistrative law. Iromcally, it is the overuse of the trial concept that has tended to damage its efficacy and hence its traditional reputation as the ultimate decisionmakmg device. In this sense, judicialization itself faces a procedural overextension similar to the substantive over-extensions plaguing the agencies. When, therefore, Congress and the courts attempt to make even informal rulemaking more and more trial-like, they not only defeat the purposes of informal rulemaking, but also undermine the integrity of the final bulwark represented by adjudication.

Referring to litigation in all of its forms, Chief Justice Burger urged attorneys to "find a better way" in his 1982 State of the Judiciary speech, ${ }^{107}$ and Justice O'Counor echoed that view a year later when slie advised that courts be viewed only as a last resort im resolving disputes. 108 Happily, we may already be experiencing somewhat of a change in this area. Although a movement toward alternative dispute resolution may still be a "inuffled explosion," 109 it has become widely enougl1 known to acquire an acronym ("ADR"), and it is now beginning to make inroads into administrative decisionmaking as well as non-administrative litigation.

For example, the Merit Systems Protection Board (MSPB), created m 1978 to hear job-related appeals from federal employees, has instituted an expedited case resolution process that emphasizes mediation by MSPB officials. ${ }^{110}$ The Commodity Futures Trading Commission has developed an innovative three-tier procedure prescribing different levels of formality and expedition for different types of cases in which customers file claims for reparation against commodity professionals. ${ }^{111}$ The

107. Isn't There a Better Way?, annual report on the state of the judiciary, delivered in Chicago on Jan. 24, 1982, reprinted in 68 A.B.A. J. 274 (1982).

108. Unpublished address given at Brigham Young University (Feb. 1, 1983).

109. Ray, Dispute Resolution: "A Muffled Explosion," NIJ REP., May 1984, at 9.

110. Lubbers, Dispute Resolution in Federal Agencies, NIJ REP., Nov. 1984, at 9. For a report on the MSPB program, see A. Adams \& J. Figueroa, Expediting SetTlement of Employee GRIEVANCES IN THE FEDERAL SECTOR (1985) (report prepared for and published by the Adininistrative Conference of the U.S.).

111. See Nelson, CFTC's New Rules: Some Innovative Approaches to Adjudication, AD. L. NEws, Spring 1984, at 1. 
dress. As in the development of the ancient forms of action in the common law, turning procedures into due process rights turns government programs into ritual acts increasingly unrelated to real human needs.

Yet another connection between the scope of government activities and overproceduralization is the result of the interaction of benefit and grant programs with the dynamism of the American society and its economy. As these programs mature, they change the social context they were created to deal with. For example, a research grant program creates a market for its own grants. A new industry develops to obtain those grants. Firms, individuals, and institutions come to be dependent upon this funding. Expectations are altered. In a democratic society with excellent communications, an ever wider constituency for these benefits develops. ${ }^{106}$ Unless an unlimited budget exists at the granting agency, there will be an ever-mcreasing disparity between the supply of and demand for benefits. Because the market mechanism is unavailable, a qualitative screening mechanism must be developed. This inevitably leads, under the influence of our due process views and the need to accommodate political pressures and the "rights" of apphicants, to everincreasing proceduralization. This, of course, causes the applicants to respond in kind, completing the frustrating-if not vicious-circle.

To the extent that overproceduralization can be said to follow inevitably from major governinent imtervention in social and econonic affairs, and to the extent that we want to change the resulting situation, we will have to make many hard substantive choices. In sonie areas we may decide that the burden of overproceduralization is the least undesirable alternative open to us. With respect to other major progranis, we niight conclude that central oversight and funding are im fact inconsistent with our basic societal values, and find a solution in either federalism or the abandonment or curtailment of those programs. Still another approach is to rethink the current concepts of due process in the area of governmental benefits law.

\section{B. Overreliance on Trial-Like Procedures.}

With respect to the second aspect of judicialization-excessive reliance on trial-like procedures-it should be noted that there is an iniportant historical bias in favor of trial-like modes of decisionmaking, a bias

106. $C f$. The Reagan Record: An Assessment of America's Changing Domestic PriORITIES 222 (J. Palmer \& I. Sawhill eds. 1984) (the traditional structure of federal matching grants and regulatory programs encourages state and local governments and special interest groups to lobby for increased funding and favorable regulation, thereby "sustain[ing] public spending and . . . insulat[ing] imtergovernmental programs from the scrutiny of taxpayers"). 
Chief Administrative Law Judge (ALJ) of the Federal Energy Regulatory Cominission uses a "settlement judge," an ALJ not otherwise involved with the case, to facilitate negotiations between the parties. ${ }^{12}$ The Department of Health and Human Services' Grant Appeals Board regularly seeks to provide or assist in the selection of a mediator to help resolve or clarify issues concerning grant disputes. Board personnel have received considerable training in mediation and negotiation techniques as part of this effort. ${ }^{13}$ In non-adjudicatory areas as well, the federal government is experimenting with departures from a trial-like mode of resolving disputes. Under its program to register pesticides, the Environmental Protection Agency's governing statute requires the use of arbitration to establish the compensation to be paid to an initial apphicant when a later applicant uses data previously subnnitted by the former. ${ }^{114}$ This provision was recently upheld by the Suprenie Court. ${ }^{115}$ And in the sometinies contentious area of rulemaking, the Federal Aviation Administration (FAA) has used "regulatory negotiation" to formulate standards to govern flight crew rest requirements. 116 The appropriateness of this approach is still being debated, but participants from business, labor, and other groups have applauded the innovation ${ }^{117}$ because it brings together interested parties to discuss and tentatively formulate the FAA's proposed rules before they are published in the Federal Register. The EPA and OSHA have also used "reg-neg,"118 and the procedure has been recominended by the Administrative Conference as a way of reducing the delay and hitigiousness that often accompanies rulenıaking. ${ }^{119}$

It would be preniature to see in these indications a major or permanent trend away from the use of trial-like procedures. Nor would such a trend necessarily result in a better, less judicialized system. Arbitration, inediation, and negotiation may ouly set the stage for even more elaborate forms of judicialization. They might, as the history of equity juris-

112. See The Settlement: "Splitting of the Differences," Monrtor June 27, 1983, at 1 (interview with Curtis L. Wagner, Jr., the Federal Energy Regulatory Commission's Chief Administrative Law Judge).

113. See Barrett, Mediation and Adjudication: The Double Track Approach, 30 FED. B. NEws \& J. 436 (1983).

114. See 7 U.S.C. § 136a(c) (1982).

115. Ruckelshaus v. Monsanto Co., 104 S. Ct. 2862 (1984).

116. See Lempert, Participants See Value in Reg-Neg's First Flight, Legal Times, Oct. 10, 1983, at 2 .

117. Id.

118. See Harter, Regulatory Negotiation: The Experience So Far, RESOLVE, Winter 1984, at 1.

119. 1 C.F.R. \& 305.82-4 (1985); cf. Harter, Negotiating Regulations: A Cure for Malaise, 71 GEO. LJ. 1 (1982) (describing and recommending a process by which agencies could engage in regulatory negotiations). 
diction illustrates, ${ }^{120}$ become as formalized and rigid, or more so, than the trial-like procedures they are designed to replace. They miglit also lead to a inasking of the underlying judicialization; their existence might be seen as a solution when in fact it only creates new probleins.

Still, the current growth in these techniques, and the willingness of the systein to experiment with thein, is healthy. Despite tlie existing emphasis on trial-like decisionmaking, apparently there is enough flexibility in the system to recognize the problem and seek a solution. This is encouraging, and deserves to be encouraged.

\section{Intrusive Judicial Review.}

Professor Davis has traced increased judicial activism in the field of administrative law to legislative prescriptions that introduced procedural requirements over and above those set fortli in the Admimistrative Procedure Act. ${ }^{121}$ Describing and applauding this development, Professor Davis has written:

[D]uring the 1970's . . . the courts [began] drawing good ideas from any and all sources, including statutes that [did] not apply to particular cases, for improving the legal requirements for ruleinaking procedure. Indeed, in extraordinary fashion, the legal frontier [was] pushed out by both judges and legislators, each stimulating the other with respect to the new ideas that [were thought to be] needed. . . . [T] he degree of interaction between judicial thinking and legislative thinking is new. The partnership of legislators and judges in the grand enterprise of producing a better legal and governmental system may be superior to what either legislators or judges can produce without the partnership and the interaction. ${ }^{122}$

In 1978, Professor-now Judge-Scalia analyzed the activism demonstrated by the Court of Appeals for the District of Columbia Circuit in imposing on agency informal rulemaking extra requirements that were not contemplated by, and in many cases contrary to the thrust of, the APA. Referring to the notion of a "partnership of legislators and judges," Judge Scalia wrote,

There may be some debate concerning the virtue or vice of legislative activism in the area of administrative procedure .... What is unquestionable, however, is that such activism cannot coexist with fundamental legislation of the sort the Court's opimion in Vermont Yankee pronounces the APA to be. Not only is legislative insouciance for the basic statute ultimately bound to infect the courts with its own spirit (as indeed it probably should), but the legislative prescription of particnlar variations from the procedural norm provides the pretext-and

120. See H. McClintock, HANdBook of the Principles of EQUity 1-12 (1948).

121. 5 U.S.C. $\$ \S 551-559,701-706,1305,3105,3344,4301,5335,5372,7521$ (1982).

122. $1 \mathrm{~K}$. DAVIS, supra note 56 , at $\$ 2.19$. 
perhaps the necessity-for the addition of judge-made variations to the statutory scheme. Witness, for example, the D.C. Circuit's conclusions that legislative prescription (contrary to the APA) of a "substantial evidence" review test for rulemaking imphicitly requires that the agency decision be made "on the record" and that "some sort of adversary, adjudicative-type procedures" be used. ${ }^{123}$

Judge Scalia found this particular "partnership of legislators and judges" to be objectionable because of the status of the APA as the fundamental set of procedural guidelines for the agencies. Departing from the APA without concern for the incoherence-a "statutory Babel"that it was bound to produce displayed, in Judge Scalia's opinion, "a devil-may-care attitude . . . [and]—even worse-a profound ignorance concerning just what . . . [was] being departed from."124 I would certainly agree with these observations. Seven years later, the trend is continuing. Congress has learned to "pass the buck" by creating layers of procedure in politically difficult substantive areas. And the courts have not impeded this developinent because procedure is, after all, the very essence of judicial activity. To the extent that procedurally-oriented judicial activisin in the administrative law area reflects Congress's departure froin the APA as the appropriate and established norm, substantive judicial activisin can be traced to the lack of a coherent and generally accepted theory on the limits and function of the administrative state.

\section{Conclusion}

General dissatisfaction with and a pervasive distrust of the administrative process as an effective way of dealing with some of our society's most iniportant concerns has led to the intellectual illusion that policy decisions-decisions of will-can somehow be made in an objective fashion by transplanting them into an apolitical setting and imposing on thein the apolitical procedures appropriate to decisions of logic. All of the foregoing factors, working together, form a powerful engine driving contemporary administrative law judicial activism, quite independent of any ideological predispositions on the part of the federal judiciary. The effect of this shift in methodology has been a predictable abdication of substantive agency prerogatives. It is simply not possible to rely to such an extent on a methodology so alien to political decisionmaking and not have those procedural preferences begin to dictate substantive results as well. If ever there was a modern illustration of the nineteenth century

123. Scalia, Vermont Yankee: The APA, the D. C. Circuit, and the Supreme Court, 1978 SuP. CT. REv. 345, 387-88 (footnotes omitted). Judge Scalia served as the Chairman of the Administrative Conference from 1972 to 1974.

124. Id. at 387. 
legal scholar Maine's remark that "substantive law has . . . the look of being . . . secreted in the interstices of procedure," 125 administrative law provides it.

The alternative to this result can only be found in a fundamental reappraisal of our governmental system. I am referring here not only to the redefinition of the limits of governmental power and the meaning of private rights, but also to the third basic area of inquiry suggested above: the need to sort out anew the constitutional powers of the branches of the federal government. The categories familiar to most of our constitutional history have had less and less practical significance since the late 1930's. No meaningful new inodel, mcorporating the realities of the adininistrative state, has taken their place. Rather, amidst the rapid ad hoc growth of the administrative state and the reactive developinent of an adininistrative law, our legal system seems to have given up any real quest for a constitutional authority for what is clearly a fundamental current feature of our government.

Lacking any real theory of the current governinental order, we have witnessed in increasing judicialization the twilight of administrative law. In this sense administrative law has bravely sought to do what cannot be done: provide a coherent rationale for a system of order, justice, and hiberty without an accepted constitutional basis. The dawn will only succeed the twilight in this region when we reconstruct a constitutional foundation upon which to rebuild a coherent and effective administrative law.

The search for a trne theory of administrative law is really the quest for a well-ordered constitutional system. I beheve it was Montesquieu, writing before the beginning of our Republic, who observed that a nation might lose its hiberties im a day, and yet not miss them for a century. Judicialization is a warning that we have begun to lose something precious. If we do lose it, it will be, I fear, much sooner than a century before we realize the full consequences.

125. H. MAINE, EARLY LAW AND CUSTOM 389 (1886). 